\title{
Legal Models of Management Structure in the Modern Corporation: Officers, Directors, and Accountants ${ }^{\dagger}$
}

\author{
Melvin Aron Eisenberg*
}

\begin{abstract}
Contrary to the legal norm, the functions of managing the business of a corporation and making business policy generally vest in the executives rather than the board. After examining the reasons why this condition prevails, Professor Eisenberg analyzes past proposals for reform, which typically have sought ways to reinvest these functions in the directors. Finding fault with the premise of these proposed reforms-that directors can successfully either manage or make business policy in modern, complex corporations-he then assesses the remaining functions of the board. His conclusion is that one such function, monitoring the performance of the chief executive's office, is both critical to the corporation and uniquely suited to the board. He therefore proposes changes in the law of corporations and corporate accounting to ensure that the board will have adequate independence and sufficient data to perform this monitoring function effectively.
\end{abstract}

A major function of corporation law is to regulate the manner in which the corporation is constituted; either directly, by distributing decisionmaking power among the various corporate organs, or indirectly, by setting the parameters within which the private actors can make such a distribution themselves. At the core of the distributive apparatus of most corporate statutes is a deceptively simple provision: "The business and affairs of a corporation shall be managed by a board of directors." ${ }^{1}$ This provision, in turn, reflects what might be called

$\dagger$ Copyright 1975 by Melvin Aron Eisenberg. Th s is the fourth and last in a series of articles on the allocation of legal powers within the modern corporation. See Eisenberg, The Legal Roles of Shareholder and Management in Modern Corporate Decisionmaking, 57 CALIF. L. REv. 1 (1969); Eisenberg, Access to the Corporate Proxy Machinery, 83 HaRv. L. REv. 1489 (1970); Eisenberg, Megasubsidiaries: The Effect of Corporate Structure on Corporate Control, 84 HARv. L. REv. 1577 (1971). ship.

Most of the research for this article was conducted during a Guggenheim Fellow-

* Professor of Law; University of California, Berkeley. A.B. 1956, Columbia University; LL.B. 1959, Harvard University.

1. Ill. Stat. ANN, ch. 32, § 157.33 (Smith-Hurd Supp. 1974). See also N.J. StaT. ANN. \& 14A:6-1 (Supp. 1968); N.Y. Bus. CoRp. LAw \$ 701 (McKinney Supp. 1974). 
the received legal model of corporate decisionmaking in general, and management structure in particular. According to this inodel, corporate operating procedure is pyramidal in form: at the base is the body of shareholders, empowered to elect the board and vote on other major corporate actions; at the next level is the board of directors, whose duties are to select officers, make policy, and generally manage corporate business; and at the pyramid's apex is the corps of officers, who "have some discretion but in general are deemed to execute policies formulated by the board." 2 It has become increasingly clear over the years, however, that under what might be called the working model of management structure-that is, the model which embodies actual corporate practice-most of the powers supposedly vested in the board are actually vested in the executives. The purpose of this Article is to explore the skew between these two models of corporate decisionmaking, to consider the inore prominent alternative models which have been suggested, and to propose a direction for reform.

\section{I}

\section{Law and Practice}

\section{A. The Received Legal Model and the Working Model}

Under the received legal model of the corporation, the board selects officers, sets policy, and generally manages the corporation's business. Under the working inodel, however, the board normally performs none of these functions. To begin with, in practice the board seldom manages the business of a corporation. "Under the system of directorates which has developed in this country among large, listed compames, directors are unable to 'manage' corporations in any narrow interpretation of the word. . . . Directors do not and cannot 'direct' corporations in the sense of operating them."3 Instead, in small, closely-held corporations the business is typically managed directly by owner-managers, ${ }^{4}$ while in large, publicly-held corporations (the principal subject of this Article) the business is typically managed by the top executives.

2. W. Cary, Corporations-Cases and Materials 150 (4th ed. 1969). See also, e.g., 1 ABA, Model Bus. Corp. ACt ANn. 752, 754 (2d ed. 1971); H. BallanTINE, Corporations 119-20 (rev. ed. 1946); N. LatTIN, THe LaW of Corporations $\S$ 69, at 239 (2d ed. 1971).

3. J. Baker, Directors and Their Functions-A Preliminary Study 12 (1945) [hereinafter cited as BAKER]. See also R. GORDON, BUSINESS LEADERSHIP IN THe Large Corporation 79-90, 114-15, 128, 134, 143-46 (2d ed. 1961) [hereinafter cited as Gokdon]; H. Maurer, Great ENTERPRise-Growth aNd Behavior of the BIg CoRporation 195 (1955) ("If outs'de di:ectors really try to manage, there is hell to pay" ") [hereinafter cited as MAURER].

4. See, e.g., M. Mace, The Board of Directors in Small Corporations 87 (1948). 
Indeed, the proposition that the board usually does not manage the corporation's business is not directly controverted by any serious student of corporate practice. It is often said, however, that the board does make business policy, ${ }^{5}$ and it is frequently implied that by making business policy the board fulfills the statutory command. ${ }^{6}$ In fact, of course, policymaking is not equivalent to management: for example, although civilians may make policy for the Army, they certainly do not manage the Army. But in any event, the typical board no more makes business policy than it manages the business. In the large, publiclyheld corporation, policymaking, like management, is an executive function. As early as 1945 the economist Robert Aaron Gordon reported in Business Leadership in the Large Corporation that in both financial and non-financial matters there was little or no indication that the boards of large companies initiated decisions on either specific matters or broad policies. While the board's approval function was more important than its initiating activities, Gordon found that "even with respect to approval, many boards in these large companies are almost completely passive," and that the final approval function was usually exercised by the chief executive in conjunction with either his immediate subordinates, an executive or finance committee of the board, or a few influent.al direc'ors acting as his informal advisors.?

Similarly, John C. Baker of the Harvard Business School reported the same year that major policies in production, marketing, finance, and personnel were usually formulated by the executives and not even formally confirmed by the board (although there was often consultation with individual directors), while in such matters as addition of new products, preparation of operating budget, and negotiation of collective bargaining ag:eements, the board's role was limited to receipt and consideration of after-the-fact reports. ${ }^{8}$ More recent studies, particularly that of Professor Myles Mace, ${ }^{9}$ have confirmed these earlier find:ngs. ${ }^{10}$

5. See, e.g., J. Bacon, Corporate Directorship Practices 93 (Nat'l Indus. Conference Bd. Studies in Business Policy No. 125, 1967) [hereinafter cited as 1967 Conference Board Survey]; 1 G. Hornstein, Corporation Law and Practice 526 (1959).

6. See, e.g., 1967 CONFERENCE BoARd SURVEX, supra note 5, at 96; BAKER, supra note 3, at 12, 131-32; H. Koontz, The BoARd of Directors aNd Effective MaNageMENT 33-44, 46-58 (1967) [hereinafter cited as KooNTZ].

7. GORDON, supra note 3, at 128-29, 131. See also id. at 114.

8. BAKER, supra note 3 , at 131-32.

9. M. MACE, DIRECTORS: MYTH aNd REALITY 47-48 and passim (1971) [hereinafter cited as MACE].

10. See, e.g., J. Bacon \& J. Brown, Corporate Directorship Practices: Role, Selection and Legal Status of THe Board 16-17 (Conference Board Rep. No. 646, 1975) [hereinafter cited as 1975 Conference Board SuRvey;] C. Brown \& E. SMITH, The Director Looks at His Job 24-26 (1957) [hereinafter cited as Brown \& SMITH]; Maurer, supra note 3, at 200-02. But see P. Holden, L. Fish \& H. SMith, TOP 


\section{B. Modern Board Practice}

The drastic skew between the received and working models of management structure is not simply an accident of time or temper. Rather, it is the virtually imevitable result of several critical constraints imposed by modern board practice.

\section{Constraints of time}

Some simple statistics: Although a board of directors normally can act only at meetings, a 1967 Conference Board study of 454 manufacturing and mining corporations found that the boards of 45 percent of the surveyed corporations met no more than six times a year, and the boards of 96 percent met no more than twelve times a year. ${ }^{11}$ Virtually identical findings emerged in a 1970 survey of 474 industrial corporations by the management-consulting firm of Heidrick \& Struggles. ${ }^{12}$ Since board meetings usually last only a few hours, ${ }^{18}$ the upshot is that

MANAGEMENT ORganization aNd CONTROL 17, 214 (enlarged ed. 1948) [hereinafter cited as Holden, Fish \& SMIth]; INvestor Responsibility Research Center, Inc., Changes in the Corporate Board Room: What Should Be Done? Who SHOULD Do IT? 5-6 (1974) [hereinafter cited as IRRC].

The same analysis is generally applicable to nonbusiness corporations. See H. WILENSKY \& C. LEBeAUX, Industrual SOCIETy aNd SOCLAL Welfare 272-73 (1958); Kerr, The School Board as an Agency of Legitimation, Sociolooy of Education, Fall 1964, at 34, 49-55.

11. 1967 CONFERENCe BoARd SuRvey, supra note 5, at 127 Table 21. The figures for other types of corporations surveyed were generally comparable, except for the public utilities (of 81 surveyed, 9.9 percent met more than 12 times a year-but none met more than 15 times-and 29.6 percent met six times or fewer) and the banking corporations (of 40 surveyed, 65 percent met 10 to 12 times a year, 30 percent met 13 to 25 times, and only 2.5 percent met fewer than 10 times). Id.

A more recent Conference Board survey of a smaller population-129 industrialsreported that just over 40 percent held 10 or more meetings per year; no breakdown was given for the 60 percent holding fewer than 10 meetings. See Brown, The Board of Directors and Its Work Routine, CONF. BD. REC., March 1972, at 36.

12. Heidrick \& Struggles, Profile of the BoARd of Directors 5 (1971) [hereinafter cited as HEIDRICK \& STRUGGLES]. The percentages for merchandising, insurance, and transportation companies were similar to those for industrials. Among the utilities, 27.8 percent held six or fewer meetings a year, and 11.1 percent held more than 12 meetings a year. Among the banking corporations, 4.4 percent held six or fewer meetings a year, and 26 percent held more than 12 meetings a year.

The Heidrick \& Struggles survey was conducted by a questionnaire sent to the 1,000 largest industrial companies, 50 largest merchandising companies, 50 largest transportation firms, 50 largest life-insurance companies, and 50 largest utilities, as ranked by sales volume in Fortune magazine, and 300 largest commercial banks, as ranked by deposits in Polk's World Bank Directory. Id. at 2. Of the corporations surveyed, 750 piovided usable responses, including 474 mdustrials, 158 banks, 26 transportation coinpanies, 23 merchandisers, 33 insurance companies, and 36 utilities. Letter from Heidrick \& Struggles to the author, Sept. 30, 1972.

13. See Koontz, supra note 6, at 158; 'Outside' Directors Are 'In', Chemicar. WEEK, August 18, 1971, at 57 [hereinafter cited as 'Outside' Directors Are 'In'li cf. 
few boards spend more than 36 hours a year in meeting time, and about half spend only 18 hours a year or less. ${ }^{14}$ Since time spent preparing for ineetings is roughly comparable to meeting time, ${ }^{15}$ it is obvious that by reason of time constraints alone the typical board could not possibly "manage" the business of a large, publicly-held corporation in the normal sense of that term:16 Such businesses are far too complex to be managed by persons who put in the equivalent of five to ten working days a year. Furthermore, the same imperative precludes the board from making business policy: In a complex organization concerned with complex choices, policy cannot be developed on a parttime basis. ${ }^{17}$

Nutt, A Study of Mutual Fund Independent Directors, 120 U. PA. L. REv. 179, 221 (1971); Townsend, Let's Install Public Directors, Bus. \& Soc'y Rev., Spring 1972, at 69.

14. Some directors may put in additional time on committee work, but this is normally reatively limited. For example, although the most common board committee is the executive committee, one-fourth of the 512 manufacturing companies included in a recent Conference Board survey did not have such a committee. J. BACON, CORPORATE Directorship Practices: Membership and Commttees of the Board 50, 54 Table 13 (Conference Board Report No. 588, 1973) thereinafter cited as 1973 CoNFERENCE BOARD SURVEY]. In those which did, one-fou: th of the committees had no outside directors, and one-fourth had only a minority of outside directors. Id. at 56 Table 15. Almost 10 percent of the executive coinumittees never met. The inedian number of meetings for those which did meet was seven per year. Id. at 55 Table 14.

15. A study conducted by the Conference Board reported that of 93 responding companies only 19 believed directors spent more time on corporate affairs outside than inside meetings. Of the reinaining 74 respondents, 36 believed about as much time was spent outside as inside, and 38 believed less time was spent-usually much less. Brown, supra note 11, at 37; cf. 'Outside' Directors are 'In,' supra note 13, at 60. See also Garrett, The SEC Study of Director's' Guidelines, CoNs. BD. REC., July 1974, at 57, 58.

16. Of course, if the board consists of officer-directors, then the individuals who do manage the corporation's business are also directors, but they do not manage the business by virtue of their directorial capacity. Similarly, large shareholders may utilize the board as a means of exercising control without actually taking a managerial role, see text accompanying notes 75-77 infra, and the board may then play an active role. But in this case too the board's force derives from nondirectorial capacities.

17. MACE, supra note 9, at 185; MAURER, supra note 3, at 200-01. Even where a part-time board does purport to make policy, the meaningfulness of its decisions may be questionable. "One executive ... remarked that he did not care who formulated the policy so long as he was left to carry it out, because he knew that by the time the operating organization had modified the so-called major policy decision to meet realities, he would have pretty inuch his own way." M. COPELAND \& A. TOWL, THE BOARD OF DIRECTORS AND BUSINESS MANaGEMENT 66 (1947) [hereinafter cited as COPELANid \& TowL].

There are, of course, cases where the board does play a meaningful role in making business policy, see MACE, supra note 9, at 48-52, but in many or most of these cases it will probably be found either that the board is dominated by executives or important shareholders, see note 16 supra, or that the business of the corporation does not involve many operating decisions. Cf. SEC, INSTITUTIONAL INVESTOR STUDY REPORT, H.R. Doc. No. 64, 92d Cong., 1st Sess. 811-14 (1971) [hereinafter cited as SEC, INVESTOR REPORT]. 


\section{Constraints of information}

Some further statistics: Although an opportunity to consider relevant data is obviously essential to meaningful decisionmaking, of 474 industrials surveyed by Heidrick \& Struggles only 17.2 percent sent directors manufacturing data prior to the meeting, only 21.3 percent sent marketing data, only 5.7 percent sent an agenda, and 11 percent sent no information at all. ${ }^{18}$ In many corporations- the executives go so far as to wholly deny the board-supposedly entrusted with supreme power over the corporation-access to certain categories of information. One-fifth of the executives questioned on this subject in both the Conference Board and Heidrick \& Struggles surveys responded that directors should not have unrestricted access to company plans and operating da:a. ${ }^{10}$

Furthermore, the board normally has no staff of its own to evaluate the information it does receive or to gather information directly. Instead, the board must rely on the executives to perform those functions, either directly or through the executives' own staff. ${ }^{20}$ Getting additional information is frequently very difficult. In many cases a director does not know what additional information he should request. Even if he does, it is regarded as improper- "just plain bad manners" to ask executives challenging questions at board meetings. ${ }^{22}$ Thus the amount, quality, and structure of the information that reaches the board is almost wholly within the control of the corporation's executives. ${ }^{23}$ It need hardly be added that this kind of power over information flow is vi: tually equivalent to power over decision. ${ }^{24}$

\section{Constraints of Composition, Selection, and Tenure}

While constraints of time and information restrict the board's abil-

18. HEJDRICK \& STRUGGLES, supra note 12, at 5 .

19. 1967 CONFERENCE BOARD SURVEY, supra note 5, at 132; HeIDRICK \& STRUGGLES, supra note 12, at 6. Sce also KoonTz, supra note 6, at 161; Weinberg, A Corporation Director Looks at His Job, 27 HaRv. Bus. REv. 585, 588-89 (1949). A note accompanying the Heidrick \& Stuuggles data states that "[a]mong [those corporations which do not give uniestricted access] . . . are organizations involved in government work, since exposure to their data necessitates security clearance," but it does not explain how many corpoiations have this problem or why the directors are not cleared.

20. See J. JuRan \& J. Louden, THe Corporate Director 287 (1966) [hereinafter cited as JURAN \& LOUDEN].

21. MACE, supra note 9 , at 54 .

22. See id. at 52-61, 186-88; Nutt, supra note 13, at 221-22. One chief executive told Mace that he liked to have insiders on the board so that he could take advantage of the "commonly observed courtesy" that the president will not be asked embarrassing questions in the presence of his subordinates. MACE, supra note 9, at 124; cf. id. at 54.

23. Cf. Copeland \& Town, supra note 17, at 169; JuRAN \& Louden, supra note 20, at 288; MACE, supra note 9, at 30; Zald, The Power and Functions of Boards of Directors: A Theoretical Synthesis, 75 AM. J. Soc. 97, 104 (1969).

24. Cf. Kerr, supra note 10, at 51; Zald, supra note 23, at 104. 
ity to manage the business or make policy, they do not directly subordinate the board to the corporation's executives. Direct subordination does necessarily follow, however, from a cluster of elements relating to the composition, selection, and tenure of directors.

a. Composition of the board. The most striking of the compositional elements is the degree to which the typical board includes persons who are economically or psychologically dependent upon or tied to the corporation's executives, particularly its chief executive. Indeed, a substantial number of seats are held by executives themselves. Employeedirectors held half or more of the board's seats in 29 percent of the approximately 500 manufacturing corporations included in a 1973 Conference Board survey, ${ }^{25} 49.8$ percent of the industrials in the Heidrick \& Struggles sample, ${ }^{26}$ and 55.9 percent of the 1970 Fortune 500. ${ }^{27}$ Dependent on the chief executive for both retention and promotion," ${ }^{28}$ and on other executives for day-to-day support, the inside director is highly unlikely to depart at a board meeting from the inside line determined by management prior to the meeting. As the corporate figures interviewed by Mace reported:

The vice president inside-director type is in a precarious position at a board meeting. He just can't say anything in disagreement with his boss, so what he usually does is sit quietly and wait until he is called upon to speak. ${ }^{29}$

Insiders don't ask questions or raise issues at board meetings because their points of view and contributions have all been expressed at meetings of management prior to the board meeting. All the insiders have been through the monthly performance review. Rarelyno, never-does the head of one operating group raise a question at the board meeting concerning the performance of another operating group. He would not do that at a board meeting. ${ }^{30}$

25. 1973 CONFERENCE BOARD SURVEY, supra note 14, at 2, 3. Among approximately 340 nonmanufacturing corporations only 14 percent had boards with insider majorities. Id. Financial institut ons in particular have traditionally had a low proportion of inside directors. Cf. id. at 3 Chart 3.

26. HEIDRICK \& STRUGGLES, supra note 12 , at 4 . In the nonindustrial categories, less than 20 percent of the banking, insurance, transportation, and utility corporations, but 65 percent of mercbandising corporations, had msider majorities or evenly divided boards. Id. at 4.

27. Sinith, Interlocking Directorates Among the 'Fortune 500', ANTITRUST L. \& EcoN. REv., Summer 1970 , at $47,49-50$. Smith's data actually covered only 495 of the Fortune 500, since information on five corporations was unavailable. Of the 495 corpo:ations, 49.7 percent had a majority of insiders and 6.2 percent were split evenly between insiders and outsiders. Id. at 50 . Of the aggregate seats in the 495 corporations, 57.5 percent were held by insiders and 43.5 percent by outsiders. Id. at $47-48$ \& Table 1 .

28. See note 88 infra.

29. MACE, supra note 9 , at 119-20.

30. Id. at 120 . 
... We have a sort of rule around here-we've even formalized it in a sense. Now, we fight like cats at the management meetings. But if any of our key inside people on the board feels strongly opposed to soinething the president is asking the board to approveand again, this doesn't happen very often-rather than go to the meeting and vote for it contrary to his judgment, he just doesn't go to that particular board meeting. This is sort of a screwy idea, but that's the way it's done here. ${ }^{31}$

Nor is dependence on the corporation's chief executive confined to inside directors. Recent surveys suggest, for example, that approxiinately one-fifth to one-fourth of the outside directors in large American corporations are lawyers or investment bankers. ${ }^{32}$ Probably most of these are suppliers of services to the corporations on -whose boards they sit, and are therefore highly interested in retaining the good graces of the chief executive, who normally has control over the purchase of such services. The same surveys indicate that approximately 12 to 15 percent of outside directors are commercial bankers, who are also often intent on retaining the corporation's business. ${ }^{83}$ Many if not most of the remaining directors are psychologically tied to the chief executive by friendship, former colleagueship, or both. ${ }^{34}$

b. Selection and tenure. As a result of current practices on selection and tenure, even those directors who are not bound to incumbent management by economic or psychological ties are unlikely to be truly independent. To begin with, directors are typically selected not by the board, as might be expected, but by the chief executive. ${ }^{35}$ In inaking these selections most chief executives will take into consideration whether the candidate can be counted on not to rock the boat.

The retired chairman of a medium-sized company in the midwest stated: . "In the companies I know, the outside directors always agree with management. That's why they are there. I have one

31. Id.

32. Smith, supra note 27 , at $48-49$ \& Table 2 (20 percent of 1970 Fortune 500); 1973 CONFERENCE BoARd SURveY, supra note 14, at 29 Table 6 (25 percent of 511 manufacturing companies). The Conference Board data is somewhat ambiguous: Of 2914 outside directors, 359 listed their principal affiliation as "law," and 299 as "investments." The Heidrick \& Struggles data does not break out figures for the occupation of outside directors.

33. Smith, supra note 27 , at $48-49$ \& Table 2 (12 percent); 1973 Conference BOARD SURVEY, supra note 14, at 29 Table 6 (15 percent).

34. See 1973 CoNperence BOARd SURvex, supra note 14, at 28 Table 4; Cabot, Management and the Director, CoNF. BD. REc., April 1974, at 50 .

35. See 1975 Conference BoArd Survey, supra note 10, at 6, 10, 12; Brown \& SMTT, supra note 10, at 109-10; GoRDoN, supra note 3, at 109, 121, 130 \& n.24, 131; MACE, supra note 9, at 94-95; MAURER, supra note 3, at 201; Pfeffer, Size and Composition of Corporate Boards of Directors: The Organization and its Environment, $17 \mathrm{AD}$. Sci. Q., June 1972, at 218, 220. 
friend that's just the greatest agreer that ever was, and he is on a dozen boards. . . ."36

Beyond the fact that he is usually selected in part because he can be counted on to go along, a new director is likely to be aligned with the chief executive simply by virtue of the fact that he owes the latter his appointment ${ }^{37}$-an element reinforced by the chief executive's role in orienting new directors to the board. ${ }^{38}$

Perhaps even more important than the power of selection, in vesting the chief executive with control over outside directors, is the fact that in life as in law the power to hire implies the power to fire. A director who has been brought on the board by a chief executiveas outside directors typically are-is therefore likely to regard himself as serving at the latter's sufferance. "Also communicated to, and generally accepted by, directors was the fact that the president possessed the complete powers of control. Those members of the board who elected to challenge the president's powers of control were advised, usually outside the board meetings, that such conduct was inappropriate or they were asked to resign." ${ }^{3}$ Nor is this power exercised infrequently: Almost 37 percent of the industrial respondents in the Heidrick \& Struggles survey reported that they had fired directors. ${ }^{40}$

Because it is inherently undesirable for law and practice to be in a state of visible opposition, the drastio skew between the legal and working models of the board would be of serious concern even if no specific dysfunctional consequences could be perceived. In fact, however, a number of such dysfunctions can be identified. On a relatively

36. MACE, supra note 9, at 99; cf. MUTUAI Funds 285 (R. Mundheim \& M. Werner eds. 1970) (remarks of Allan F. Conwill); University of Pennsylvania Law School Conference on Mutual Funds, 115 U. PA. L. REv. 663, 739 (1967) (remarks of Abraham L. Pomerantz). As one executive was quoted:

"Here in New York it's a systems club. There is a group of companies ... where the chief executive of Company $A$ has $B$ and $C$ and $D$ on his board. They are all members of the Brook Club, the Links Club, or the Union League Club. Everybody is washing everybody else's hands." MACE, supra note 9, at 99.

37. Cf. 1975 Conference BonRd SURVex, supra note 10, at 25; Moscow, The Independent Director, 28 Bus. LAw. 9, 11 (1972); Nutt, supra note 13, at 219.

38. Cf. BRown \& SMITH, supra note 10, at 88-89; Nutt, supra note 13, at 219.

39. MACE, supra note 9, at 80. See also id. at 79, 80-81; 1975 CoNFRRENCE BOARD SURVEY, supra note 10, at 10.

40. HeidRICK \& STRUGGLes, supra note 12 , at 11 . Some of these firings may have been attributable to poor performance rather than insubordination.

The percentage of other types of companies which had fired directors ranged from 32.3 to 38 percent, except for the utilities, only 11.1 percent of which reported such firings.

Legally, of course, the chief executive does not have power to discharge a director; however, a recalcitrant director can be dropped simply by arranging that he is not renominated when his term expires. 
particularistic level, many legal rules have been shaped on the premise that the board manages the corporation's business in fact as well as in law. For example, by proceeding from the assumption that officers play a subordinate role to the board, the rules governing the authority of officers frequently embody an unrealistically restrictive view of an officer's power of position. ${ }^{41}$ Standards of care, by the same token, often seem to be pitched to the outside director rather than the executive, as if the former were really running the business. ${ }^{42}$ In duty-ofloyalty cases the courts have often given disproportionate weight to the fact that outside directors have approved a transaction in which executives are interested, ${ }^{43}$ while the legislatures have sometimes gone so far as to provide that approval by outside directors is sufficient to sterilize an otherwise infected transaction. ${ }^{44}$ In a wider context, the skew between belief and reality has led to what might be called the quackcure problem-the danger that behef in the validity of the received legal model will forestall meaningful regulation by lulling shareholders, legislators, and the public into the illusion (which often seems deliberately conjured-up ${ }^{45}$ ) that a disinterested board is supervising the corporation's affairs. ${ }^{46}$

41. See, e.g., Schwartz v. United Merchants \& Mfrs., Inc., 72 F.2d 256 (2d Cir. 1934); Phoenix Western Holding Corp. v. Gleeson, 18 Ariz. App. 60, 500 P.2d 320 (1972); Hurley v. Ornsteen, 311 Mass. 477, 42 N.E.2d 273 (1942); Douglass v. Panama, Inc., 504 S.W.2d 776 (Tex. 1974).

42. See, e.g., Graham v. Allis-Chalmers Mfg. Co., 41 Del. Ch. 78, 188 A.2d 125 (Sup. Ct. 1963); Glassberg v. Boyd, 35 Del. Ch. 293, 116 A.2d 711 (1955).

43. See, e.g., Meiselman v. Eberstadt, 39 Del Ch. 563, 568, 170 A.2d 720, 723 (1961); Beard v. Elster, 39 Del. Ch. 153, 164.65, 160 A.2d 731, 738 (Sup. Ct. 1960).

44. See, e.g., DEL. CODE ANN. tit. 8, \$ 144(a) (1) (Michie 1975).

45. Cf.Amex Votes to Reshape its Structure, N.Y. Times, June 8, 1972, at 69, col. 6; Exchange Members Grant the Public a Louder Voice, N.Y. Times, March 2, 1972, at 55, col. 7; Metz, Directors' Role at Exchanges, N.Y. Times, Dec. 26, 1972, at 54, col. 4; Price of Friendship: How Rich Acquaintances of California Publisher Evidently Lost Bundle, Wall St. J., Aug. 11, 1972, at 1, col. 1; Public Directors Cautious at Big Board, N.Y. Times, May 21, 1973, at 51, col. 5 .

46. See MACE, supra note 9, at 107-08; S. VANCE, The Corporate DirectorA Critical Evaluation 63-68 (1968) [hereinafter cited as Vance]; Cary \& Harris, Standards of Conduct under Common Law, Present Day Statutes and the Model Act, 27 Bus. Law., Feb. 1972, at 61, 65-66 (special issue) (remarks of Professor Cary); Heineman, What Does and Doesn't Go On in the Boardroom, FoRTUnE, Feb. 1972, at 157, 159; Zald, supra note 23, at 103; Townsend, Book Review, N.Y. Times, Dec. 12, $1971, \S 7$ (Book Review), at 3.

For example, in the Investment Company Act of 1940 Congress sought to regulate conflicts of interest between investment coinpanies and their investment advisers, which were typically under common control, primarily by directing that no more than 60 percent of an investment company's board could be affiliated with its investment adviser in specified ways, and that contracts between an investment company and its adviser required periodic approval by either the shareholders or a majority of the unaffiliated directors. Investment Company Act of 1940, $\$ \S 2(a)(3), 10(a), 15(a)-(c), 54$ Stat. 790, $806,812-13(1940)$. In practice this technique of regulation turned out to be virtually worthless, because the unaffiliated directors of investment companies, like the outside 
II

\section{PROPOSALS FOR REFORM OF THE BOARD: BRINGING THE WORKING MODEL INTO LINE WITH THE RECEIVED LEGAL MODEL}

Given the skew between the legal and working models of management structure, and the resulting dysfunctions, it is not surprising that proposals for reform of the board have become a permanent part of the American corporate scene. Most of these take the received legal model as a starting point and seek to bring corporate practice into line. Froin that point on, however, the proposals show wide variation, falling into three broad categories: those calling for professional directors; those calling for full-time directors; and those calling for fully-staffed boards.

\section{A. Professional Directors}

One common type of proposal calls for filling board places with persons who would make a career out of serving as directors in a number of corporations, and would therefore presumably be more expert in and nore attentive to their directorial obligations-so-called professional directors. ${ }^{47}$. It is unlikely that private action could be depended upon to effectuate such a reform. Over 88 percent of the corporations in the Heidrick \& Struggles survey, including 85 percent of the industrials, reported that they had no interest in using professional directors..$^{48^{\circ}}$ Yet it is equally unlikely that such a reform could be effected

directors of other corporations, were not in control of the board, were selected and indoctrinated by insiders who represented the investment adviser, and were often closely tied to insiders even though not technically "affiliated." See SEC, INVESTOR REPORT, supra note 17, at 207-15, 363-64; SEC, REPORT ON PUBLIC POLICY IMPLICATIONS OF INVESTMENT COMPANY GrowTH, H.R. REP. No. 2337, 89th Cong., 2d Sess. 10-17, 94-125, 150-51, 162-78 (1966); Wharton Sceool of Finance \& COMmerce, A Study of MUTUAL Funds, H.R. REP. No. 2274, 87th Cong., 2d Sess. 27-36, 463.66, 475-539 (1962) [hereinafter cited as WHARTON REPORT]; Nutt, supra note 13, at 184, 215-20. But see University of Pennsylvania Law School Conference on Mutual Funds, supra note 36, at 741, 755 (remarks of Joseph E. Welch).

The Investment Company Act was overhauled in 1970. Among other things, a specific duty was imposed on mvestment company directors "to request and evaluate . . . such information as may reasonably be necessary to evaluate the terms" of the investment-adviser contract, and a fiduciary duty was explicitly imposed on the adviser with respect to its compensation. 15 U.S.C. $\$ \S 80 \mathrm{a}-15(\mathrm{c}), 35(\mathrm{~b})$ (1970). See Nutt, supra note 13 , at 265 .

47. See, e.g., W. Douglas, Democracy and Finance 52-55 (1940); Holden, Fish \& SMiTt, supra note 10 , at 225; JURAN \& LoUdEN, supra note 20 , at 331-33; cf. Bacon, Directors Under Pressure, Conf. BD. REc., Feb. 1972, at 44, 44-45 (remarks of James E. Robison).

'48. Heidrick \& Struggles, supra note 12, at 10. See also JuRAN \& Louden, supra note 20 , at $333-35$.

In addition, 64.5 percent of the surveyed corporations, including 56.7 percent of the industrials, had no interest in using retired executives as directors, and most of the re- 
by law. For one thing, it would be extrenely difficult to define the term "professional director" statutorily. For another, it is questionable whether a suitable population of potential appointees presently exists; in a 1973 Conference Board survey of 851 boards, for example, only 75 seats were held by persons who considered themselves to be professional directors. ${ }^{48}$ Although the population problem might be mitigated by extensive use of retired executives, that solution would simply foster another, equally difficult problen: the creation of a corporate gerontocracy, in conflict with the recent trend toward setting a retirement age for directors as well as executives. ${ }^{50}$

Even putting aside the difficulties of making such a proposal operational, the wisdoin of putting it into effect scems very doubtful when its implications are considered. Because directorships under present corporate practice are part-time positions, directorship fees are relatively low: median annual compensation for board service is in the $\$ 3400-4800$ range. $^{51}$ To earn a living as a professional director coinmensurate with the skills required, an individual would therefore need to hold upwards of a dozen directorships. ${ }^{52}$ Assuming that the number of large publicly held corporations for which such a reform might sensibly be required is approximately $2750,{ }^{53}$ that the average number of outside directorships in such corporations is six, ${ }^{54}$ and that all outside seats would be filled by professional directors, approximately 15,000 . 16,000 seats would have to be filled in this manner. If each director were to hold a dozen seats, all of these directorships would be filled by just 1300 individuals. Not only would this generate an enormous and institutionalized conflict-of-interest problem but, what is worse, the

maining corporations had no interest unless there was an age restriction. HeIDRICK \& STRUGGLes, supra note 12 , at 10.

49. 1973 CONFERENCE BOARd SURvey, supra note 14, at 29 Table 5, 39 Table 9. See also 1975 CONFERENCE BOARD SURVEY, supra note 10, at 40.

50. See 1973 Conference BoArd SurVey, supra note 14, at 42-47; Heidrick \& STRUGGLes, supra note 12, at 10; JURAN \& LOUdEN, supra note 20, at 182-83; cf. Brown \& SMITH, supra note 10, at 117; Companies Act of 1948, 11 \& 12 Geo. 6, c. 38, § 185 (special notice required for resolution appointing a director over the age of 70 ).

51. J. Bacon, Corporate Directorship Practices: Compensation 3 Chart 3 (Conference Board Rep. No. 596, 1973). This range includes both manufacturing $(\$ 4800)$ and nonmanufacturing $(\$ 3400)$ corporations.

52. Cf. Vanderwicken, Change Invades The Boardroom, ForTune, May 1972, at $156,282$.

53. This figure is based on the number of common stock issues traded on the New York and American Stock Exchanges. Letter from Dorothy Geraghty, Research Associate, New York Stock Exchange, to the author, Mar. 3, 1975 (1542 issues); Letter from Robert A. Coplin, Vice-President, Information Services Division, American Stock Exchange, to the author, Feb. 27, 1975 (1222 issues).

54. The data permits only an estimate on this point, but the figure of six seems fairly reliable, and a range of five to eight would be highly reliable. See 1973 CoNFERENCE BoARd SURVEy, supra note 14, at 1-2; Heidrick \& Struggles, supra note 12, at 4 ; Smith, supra note 27 , at 48 . 
professional directors would form an interlocking communication network tying the country's major corporations together in a wholly undesirable way. ${ }^{55}$

Finally, one may doubt the accuracy of the premise that professional directors are more likely than nonprofessionals to be meaningfully involved in managing the corporation's business or making business policy:

In England, where they have a "profession" known as "company director," the boardroom life is popularly regarded as a cushy sinecure. Said Lord Boothby, a life peer, in a reflective moment: "If you have five directorships it is total heaven, like having a permanent hot bath .... No effort of any kind is called for. You go to a meeting once a month in a car supplied by the company, you look grave and sage, on two occasions say 'I agree,' say 'I don't think so' once, and if all goes well you get 500 pounds a year."so

\section{B. Full-Time Directors}

A second type of proposal for bringing board practice into line with the received legal model is the restriction of board membership to "full-time directors," that is, individuals who' are in the corporation's employ on a full-time basis, but differ from executives in that they do not have operating responsibilities. ${ }^{57}$ Such a model lifts from the board the time constraint that in itself debars most directors from making business policy. An official of Standard Oil of New Jersey, which had such a board for many years, ${ }^{58}$ put the argument as follows:

[I]t's just inconceivable that a director in a corporation can discharge the [director's] responsibilities . . . unless he does more than attend

55. Cf. Smith, supra note 27; Smith \& Desfosses, Interlocking Directorates: $A$ Study of Influence, Miss. Vall. J. Bus. \& EcoN., Spring 1972, at 57. See also Clayton Act $\$ 19,15$ U.S.C. $\$ 19$ (1970) (". . . . No person at the same time shall be a director in any two or more corporations, any one of which has capital, surplus, and undivided profits aggregating more than $\$ 1,000,000$. . if such corporations are or shall have been theretofore . . . competitors. . . ."); Protectoseal Co. v. Barncik, 484 F.2d 585 (7th Cir. 1973); F.T.C. Says 3 Concerns Violate Law on Directors, N.Y. Times, Nov. 25, 1972, at 1, col. 2; Goodyear Chairman Quits Alcoa Board; FTC is Notified, Wall St. J., Dec. 1, 1972, at 6, col. 1; Kerr-McGee's Head Leaves Outside Board, N.Y. Times, July 11, 1974, at 48, col. 1; Legal Actions Prompt Directors to Reassess Their Corporate Roles, Wall St. J., Sept. 17, 1974, at 1, col. 6; Littlefield Quits Board at Chrysler, Remains at GE After FTC Move, Wall St. J., March 23, 1973, at 9, col. 1; Second Alcoa Director Cited by FTC Quits a Post, Case Against 3 Firms May Go On, Wall St. J., Dec. 4, 1972, at 7, col. 1; 25 on Boards of Oil Companies Scrutinized in Antitrust In* quiry, N.Y. Times, March 12, 1974, at 1, col. 8. But cf. Tow1, Outside Directors Under Attack, HaRv. Bus. Rev., Sept.-Oct. 1965, at 135.

56. Chamberlain, Why It's Harder and Harder to Get a Good Board, FoRTuNe, Nov. 1962, at 109.

(57) See generally Brown \& SMITH, supra note 10, at 57-93.

58. See id. at 57; VANCE, supra note 46, at 190-91. 
a board meeting once a month. Unless he works in between those monthly board meetings very hard, he'd coine up with a lot of statistics and have a lot of office traffic, but the real issue is whether a director of a corporation can or cannot discharge his responsibilities adequately . . . if he does not know enough about the functioning of the managers who are implementing board policy, and the results that they obtain, to form of his own knowledge proper opinion about what's going on.

Now that means, as I say, he's got to be something more than a once-a-month director. ${ }^{58}$

As with the professional director, however, it is doubtful that the full-time director concept could be implemented by law. The distinction between operating and nonoperating decisions is not sufficiently clear to be the subject of legislative mandate, and even if it were, most corporations could not easily develop or afford a complete set of fulltime top managers who had no operating responsibilities. ${ }^{\circ 0}$ Finally, even if problems of statutory definition were overcome and the requirement restricted to those corporations which could afford it, the wisdom of precluding corporations from combining operating and nonoperating functions in the saine individuals is doubtful, since in many businesses the major nonoperating functions (such as measurement of divisional performance, allocation of resources among divisions, determination of corporate-wide business principles, and establishment or acquisition of new businesses) cannot be compartmentalized from operating decisions. $^{61}$

59. BRown \& SMITH, supra note 10 , at 58 .

60. See id. at 62-63; JURAN \& LOUDEN, supra note 20, at 170-71.

61. In 1966 Jersey itself significantly changed its full-time director concept by adding part-time outsiders to its board and transferring the old board's functions to a reconstituted full-time executive committee. VANCE, supra note 46, at 191.

Perhaps partially in recognition that a board consisting solely of full-time directors is unfeasible in most cases, a variant of the full-time director concept has come into prominence within the last several years. Under this variant, a few (but less than all) of the directors, without taking on management responsibilities, would spend a significant portion (but less than all) of their time directly involved with the corporation's business. See, e.g., Patton, The Working Director-Management's Middleman, Cons. BD. REC., Oct. 1972, at 36. Several major corporations have put such a concept into practice. For example, Westinghouse announced in 1972 that its top executives would retire from their managerial positions at 60 , rather than at 65 , and would then "be retained as 'officer-directors,' reporting to the board on a variety of significant long-range problems. The 'officer-directors' would spend two-thirds of their time on corporate business until the normal retirement age of 65 , and would draw two-thirds of their previous salaries . . . Westinghouse to Cut Top Officers' Duties at Age 60 to Facilitate Succession Process, Wall St. J., July 12, 1972, at 8, col. 2; see 1975 Conference Board SURVEY, supra note 10, at 36. See also id. at 37-39; Vanderwicken, supra note 52, at 282, 290. Again, such a practice would be difficult to require in operative statutory terms. Furthermore, such arrangements in themselves seem to hold out little gain over present practice, since such special directors are likely to be super-consultants, dependent 


\section{Fully Staffed Boards}

Still a third type of proposal calls for equipping the board with a substantial staff of its own to advise it in reviewing management proposals and thereby allow it to exercise at least a policymaking-if not a.managerial-role. ${ }^{62}$ The best known and most complete proposal of this type was made by Arthur J. Goldberg in 1972 at the time of his resignation from the board of TWA.

The Goldberg proposal begins by pointing up the skew between the received and working models of the board, and the inevitability of such a skew under current corporate practice. Since outside directors "cannot acquire more than a smattering of knowledge about any large and far-flung coinpany," the board "is relegated to an advisory and legitimizing function that is substantially different from the role of policy maker . . . contemplated by the law of corporations." As a result, "[i]t is difficult, if not impossible . . . for the most dedicated director to have much impact on policy decisions." Thus the outside director is not fulfilling the policy-making role contemplated by corporate law, leaving him "open to justifiable criticism and legal recriminations." The cure proposed for these ills is the establishment of "a committee of overseers of outside directors" which "would be generally responsi-

on management for their positions, for their support, and for acceptance of any proposals they might make. Cf. Patton, supra, at 38.

A variant of the variant calls for a special director who would be nominated or approved by some organ independent of the corporation and who would have special responsibilities and special facilities. See Moscow, supra note 37; Townsend, supra noto 13. Under Moscow's proposal such a director would be expected to devote at least 12 working days annually to the corporation's business (in addition to attending board meetings), and would have the purpose of promoting "the long term business success of the corporate enterprise. . . . [and representing] the collective body of future shareholders. . . ." Moscow, supra note 37, at 12. This seems like quite a lot to do in 12 days. Townsend's proposal, which would apply only to corporations with over a billion dollars in assets, calls for the appointment of a full-time "public director" by an ad hoc committee of congressional members. The corporation would give this official an office on its premises and a million dollars a year with which to pay his own salary and hire staff. He would "receive notice of all meetings conducted throughout the company [which would be] automatically open to attendance by him or one of his staff members." Townsend, supra note 13, at 69 (emphasis in original). He and his staff would have access to all files. He would be required to call two press conferences a year to "report on the company's progress or lack of progress on issues of interest to the public. It will be argued that he will reveal company secrets. Let us pray he will." Essentially, this is not an idea for a new kind of director, but for an observer posted at the corporation by the state. The staff would be the observer's, not the board's; the obligations would run to the public, not to the corporation. While the title of "director" might flow from the historical evolution of Townsend's proposal, it is irrelevant to the proposal's substance. For the kinds of difficulties such a proposal might involve, see note 106 infra.

62. See, e.g., Koontz, supra note 6, at 169-70.

63. Goldberg, Debate on Outside Directors, N.Y. Times, Oct. 29, 1972, $\$$, at 1, col. 3. See also N.Y. Times, Oct. 19, 1972, at 69, col. 5. 
ble for supervising company operations on a broad scale and make periodic reports to the board." This committee would be authorized to hire a small staff of experts "who would be responsible only to the board and would be totally independent of managenent control," and to engage highly skilled consultants-such as scientific advisors, demographic experts, consumer advisors, advertising consultants, and financiers-to provide an independent source of expertise for the board. Together, the staff and consultants "would look into inajor policy questions and report to the committee and through thein to the board as a whole before decisions are taken on management recommendations." This assistance "would reassert the position of the board as a focal point for creative policy input for corporate decisions."

The Goldberg proposal carries to its logical conclusion the proposition that the working model of the board must be brought into line with the received legal model. Given the premise that the board is to inanage the business of the corporation (or at a mimimum make business policy), it follows that unless the board is to consist of full-time corporate employees, which would be prohibitively costly and possibly inefficient in most corporations, it must have at its disposal a staff and consultants to scrutinize management's activities, policies, and proposals preliminary to review and revision by the board.

Notwithstanding its logic, however, the Goldberg proposal is both unsound and unworkable. Stripped of its trappings, it would create a shadow staff with an institutionalized obligation to second-guess the management, but with very limited responsibility for results. Assuming that the directors are part-time, in cases where the recommendations of staff and managenent diverged they would have little choice except to adopt one set of recommendations or the other. Yet absent selfdealing on the part of inanagement, the board's staff could normally be expected only to decide again-with much more limited facilities and feel for the business, and at the price of additional expense and time-issues which management and the corporate staff have already once decided. If the conclusions of managennent and staff are the same, nothing will have been gamed for this price. If they differ, it is far from clear how the board will choose between them. In short, the proposal would add a further and unnecessary level of decisionmaking to corporations which already tend toward overbureaucratization; would add immensely to the difficulties of running the corporation's business; and would produce a wholly undesirable diffusion of responsibility as among the executives, the shadow staff, the overseeing committee, and the board itself. ${ }^{65}$

64. Goldberg, supra note 63 , at 3.

65. Cf. Blough, The Outside Director at Work on the Board, 45 N.Y. STATE B.J. 


\section{III}

\section{The Functions OF THE BOARD}

Given that the Goldberg proposal carries to its logical conclusion the premise that the working model of the board should be brought into line with the received legal model, and given further that the proposal is both unworkable and unsound, its ultimate thrust is to demonstrate, however inadvertently, the invalidity of the premise from which it proceeds: Since the board cannot be expected either to manage the business or make business policy, the task of reform must lie not in aligning the working model of the board with the received legal model, but in structuring the board to ensure effectuation of any meaningful functions it can perform, and particularly any functions it is uniquely qualified to perform.

With management and pohcymaking beyond the board's reach, four clusters of functions reniain: providing advice and counsel to the office of the chief executive; authorizing major corporate actions; providing a modality by which persons other than executives can be formally represented in corporate decisionmaking; and selecting and dismissing the members of the chief executive's office and monitoring that office's performance. ${ }^{68}$ In considering the bearing of each of these functions on the structure of the board, two related questions must be

467 (1973); Smith, The Goldberg Dilemma: Directorships, Wall St. J., Feb. 7, 1973, at 14 , col. 4. Blough points out that while the Goldberg proposal is grounded in significant part on protecting the director against liability for failure to obey the statutory mandate that he manage the corporation, it

would raise as many legal problems for a safety-first minded outside director as it would settle. If a conflict among staffs arose, some comfort could be taken legally in the board's having considered all viewpoints and its conclusion thus should not ordinarily be questioned by a court under the "business judgment" rule. But the directors would also have to consider ... . the comparability of the quality of the outside staff with the mside group, the possibility that a dissident stockholder would claim that because of a disclosed adverse report the board knew or should have known the investment would turn sour, or that confronted by conflicting views the board did nothing when it should have taken advantage of a golden opportunity.

Blough, supra, at 470.

For a more sympathetic view of the Goldberg proposal, see Schwartz, A Plan to Save the Board, 28 RECORD OF N.Y.C.B.A. 279 (1973).

66. Another function sometimes attributed to the board is handling crisis situations. See, e.g., MACE, supra note 9, at 27. On examination, however, this function invariably boils down to selecting a new chief executive when the incumbent dies unexpectedly or when the corporation is in deep trouble due to his madequacy, see id., and is therefore really a special case of the selection-and-dismissal function.

The asking of pertinent questions is also sometimes listed as an important board function. See BAKER, supra note 3, at 19; CoPELAND \& TowL, supra note 17, at 95114; KOONTZ, supra note 6 , at 39-40. In fact boards seldom ask such questions, see text accompanying notes $21-22$ supra, but even if they did it would simply be an application of the functions described in the text. 
asked: How important is the function; and to what extent is the board uniquely qualified to perform it?

\section{A. Advice and Counsel}

It is commonly stated that a major function of the board is to provide advice and counsel to the corporation's chief executive. ${ }^{87}$ Certainly a director is in many ways ideally suited to fill such a role. As a member of the corporate institution he has both a reasonable degree of familiarity with its business operations and a special set of loyalties to its welfare. And because he is a formal equal of the chief executive, he may be free to speak his mind in a way that is closed to the chief executive's subordinates, while the chief executive may be able to discuss with him matters that could not easily be raised with subordinates. ${ }^{68}$ On the other hand, the advice-and-counsel function is hardly essential to the corporation's operation. The chief executive could perform his own functions with advice only from staff and line. If the chief executive does want outside advice, he can and frequently will obtain it froin the corporation's lawyers, accountants, or bankers, rather than from the board. Indeed, the fact that a given director is a professional often better accounts for his advice being sought than the fact that he is a director.

\section{B. Authorization of Major Corporate Actions}

Many kinds of corporate actions require authorization by the board of directors as a inatter of either law or practice. The statutory direction that the corporation's business be managed by the board serves to impose a requirement of board authorization for transactions of a certain quantitative magnitude, regardless of type-a requireinent normally pohiced by third persons involved in such transactions. The statutes also commonly require board authorization of certain types of transactions regardless of quantitative magnitude-typically dividend declaration, certificate amendment, merger, sale of substantially all assets, and dissolution. ${ }^{69}$ Furthermore, the internal operating procedures of unany corporations require board authorization for capital investments, acquisitions, long-term commitments, and other defined types

67. See BRown \& SMITH, supra note 10, at 19 (remarks of unidentified director); GorDoN, supra note 3, at 135-37; MAce, supra note 9, at 13-22; Bacon, supra note 47, at 44 (remarks of Gustave L. Levy); Vanderwicken, supra note 52, at 157; Weinberg, A Corporation Director Looks at His Job, HARv. BuS. REv., Sept. 1949, at 591.

68. See 1975 CONFERENCE BOARD SURVEY, supra note 10, at 18; Vanderwicken, supra note 52, at 157-58.

69. See Eisenberg, The Legal Roles of Shareholders and Management in Modern Corporate Decisionmaking, 57 CALIF. L. REv, 1, 60-68 (1969). 
of transactions involving some designated dollar amount. ${ }^{30}$

Certamly the authorization function may be a useful one. Even pro forma review is likely to inhibit practices which cannot stand even superficial scrutiny. ${ }^{71}$ Moreover, the mere expectation that review is required before a plan can becoine effective probably heightens the rationality of the decision process by inducing extra care in the preparation of proposals. ${ }^{72}$ Finally, providing the chief executive with an organ to which he is accountable, even in form, may dissipate somewhat the strains which accompany ultimate substantive responsibility. A leading executive has remarked that the board "buffers and protects the chief executive and provides him and his subordinate management with a sheltered and supportive environment in which to function."73

On the other hand, beyond serving as an audience, and a generally agreeable one at that, the board's reviewing role is usually quite limited, since its decisions must normally turn on analyses prepared by the very executives who formulate that which is being analyzed. Furthernore, the audience role itself can be played with inore effectiveness elsewhere in the corporate structure, and it generally is. Since the modern corporation is highly bureaucratic, most plans must go through several layers of review even in the absence of a requirement of board approval. In all likelihood any one of these reviews has greater potential for disclosing a proposal's weaknesses than does review by the board. Indeed, for most or all practical purposes the last real authorization level is the office of chief executive. ${ }^{74}$ Thus, aside from the potential check it provides in conflict-of-interest cases, the board's authorization function, like its advice-and-counsel function, is of limited importance.

\section{A Modality for Exercising Influence or Control}

A third function served by the board is the provision of a modality through which classes of persons other than the corporation's executives can influence or control corporate action. For example, major shareholders may want to become meaningfully involved in corporate decisions, yet may not wish to take on an executive position. Exercise of control through formal shareholder channels is likely to be unsatisfactory in such cases because the body of shareholders may not be legally

70. See, e.g., 1967 CONFERENCE BOARD SURVEY, supra note 5, at 97; KoONTZ, supra note 6 , at $45-53$.

71. Nutt, supra note 13 , at 223.

72. See KoonTz, supra note 6 , at 24 ; $c f$. id. at 23-24; H. WILENSKY \& N. LEBEOUX, INDUSTRIAL SOCIETY AND SOCIAI Welfare 273 (1958).

73. Heineman, supra note 46 , at 157 .

74. See GoRDON, supra note 3, at 131-33. 
permitted to make the relevant decisions, ${ }^{75}$ and in any event inay constitute too clumsy an instrument for this purpose. Exercise of control through informal channels inay be undesirable because such a role may subject the shareholder to mdividual liability, ${ }^{76}$ and in any event may be unsatisfactory just because of its informality. For such shareholders the board provides an ideal modality, smce internal corporate processes can be so structured that all transactions of a given class must go through the board or a board coinmittee on which the shareholder sits. ${ }^{77}$

Major sliareholders are not the only persons who want to use the board as a modality for involvement in corporate decisionmaking. Major creditors often make similar use of the board for similar reasons, ${ }^{78}$ and lately inuch consideration has been given to the desirability of providing various corporate client groups (for example, employees, suppliers, consumers), and certain disadvantaged social groups (sucli as blacks and women) with access to the corporate decisionmaking process through board membership. ${ }^{79}$

How important is the modality function? For a major shareholder or creditor the mechanisin is certainly useful. For the other groups the answer is less clear. Membership in such groups does not guarantee either the financial and business skills or the time required to exert a meaningful say in corporate decisionmaking. In all probability, some client and social groups press for board representation because they fail to realize this and also overvalue the board's role. But even a group that is aware of the limited utility of board membership might want such representation. While normally the board can, as a practical matter, neither manage the business nor make business policy, it may be able

75. See, e.g., Charlestown Boot \& Shoe Co. v. Dunsmore, 60 N.H. 85 (1880).

76. See Kingston Dry Dock Co. v. Lake Champlain Transp. Co., 31 F.2d 265 (2d Cir. 1929) (L. Hand, J.).

77. See, e.g., O. Williamson, THE Economics of Discretionary Behavior: MANAgerial ObJectives in a THeory OF THE Firm 105 (1964); cf. Great Western United's Board Reestablishes Executive Committee, Wall St. J., July 31, 1972, at 1, col. 4; Great Western United Faces Proxy Fight as Director Backs Disposal of Some Units, Wall St. J., Aug. 23, 1972, at 6, col. 1.

78. As im the case of a shareholder, direct involvement in corporate decisionmaking by a creditor may result in the imposition of individual liability. Cf. Connor v. Great W. Sav. \& Loan Ass'n, 69 Cal. 2d 850, 447 P.2d 609, 73 Cal. Rptr. 369 (1968) (Traynor, C.J.).

79. See Blumberg, Reflections on Proposals for Corporate Reform Through Change in the Composition of the Board of Directors: "Special Interest" or "Public" Directors, 53 B.U.L. REv. 547 (1973); Bunting, Conard, Deutsch, Farrell \& Hickman, The Corporate Machinery for Hearing and Heeding New Voices, 27 Bus. LAw. 195, 197-208 (remarks of Professor Alfred F. Conard), 214-18 (remarks of John R. Bunting) (1971); PoKempner, The More Representative Board, CoNF. BD. REc., Feb. 1972, at 42; Vanderwicken, supra note 52, at 285-90; cf. Firms Find Integration in their Boardrooms is Working Quite Well, Wall St. J., Oct. 5, 1972, at 1, col. 6. 
to impress upon those who do the importance of taking particular kinds of values into account. At a minimum, the allocation of directorships to certain groups may concretely symbolize, to imddle and lower management, top management's commitment to the values which the group represents. ${ }^{80}$

On the other hand, there are alternative modalities through which the ends desired by such groups can be achieved. These alternatives can be ranged along a continuum, with informal channels of influence at one extreme and direct government regulation at the other. Between these poles lie a great variety of formal modalities. For example, labor can gain a say in corporate decisionmaking through collective bargaining and the grievance machinery. ${ }^{81}$ Creditors can exercise control through restrictive covenants. ${ }^{82}$ Suppliers and consumers can be organized either through private action, as in the case of American automobile dealers, ${ }^{83}$ or under legal auspices, as in the case of the consumer councils created by statute in cormection with socialized industries in Great Britain. ${ }^{84}$ Social groups can gain a say through working relationships developed between the corporation and representative organizations. ${ }^{85}$ These modalities may be more effective inechanisms than board membership for the exercise of influence by client and social groups, since they can be closely tailored to the substantive and procedural needs of each group, while the board's form is relatively fixed, its jurisdiction necessarily diffuse, and its effective power very limited.

Furthermore, board representation by such groups entails costs that nuay outstrip any potential benefits. For one thing, a director appointed to represent such a group may face the difficult and at times irreconcilable problems which result from attempting to promote two potentially conflicting objectives: the best interest of the corporation, and the special interests of those whom the director represents. ${ }^{86}$ Moreover, the special interests of the various groups represented under

80. See Blumberg, supra note 79, at 552; Bunting, et al, supra note 79, at 201 (remarks of Prof. Conard), 215-17 (remarks of Mr. Bunting); Vanderwicken, supra note 52, at 290; cf. City to Add Nurses to Hospital Boards, N.Y. Times, Aug. 2, 1966, at 1, col. 7.

81. See J. Kunn, Bargaining in Grievance Settlement (1961); Feller, $A$ General Theory of the Collective Bargaining Agreement, 61 CALIF. L. REv. 663 (1973).

82. Cf. American bar foundation, Corporate Debt Financing Project, ComMENTARIES ON INDENTURES 312-473 (1971).

83. Cf. S. Macaulay, LaW aNd the Balance of Power (1966).

84. See W. Robson, Nationalized INDUstry and PUblic OWNership 243-77 (1960).

85. Cf. R. Walton \& R. McKersie, a Behaviorat Theory of Labor NegotiaTIONS 391-98 (1965).

86. Cf. Vagts, Reforming the "Modern" Corporation: Perspectives From the German, 80 HARV. L. REv. 23, $52-53$ (1966). 
such a concept are themselves likely to conflict, with consequences that have been pointed up by Professor Vagts:

The system [adopted under German law and practice, under which the supervisory board includes labor, banking, supplier, and big-consumer representatives] has . . special dangers. By bringing the public and the employees into the inner councils of the corporation it tends to screen both the conflicts between the interests involved and their resolution from public view. Thus it causes power to be exercised by a relatively closed group that tends to develop cominon alliances within itself at the expense of those whom it represents. ${ }^{87}$

In short, while the problem of board representation by client and social groups is a complex one, for present purposes it seems fair to conclude that some benefits derive from such representation; that the benefits probably consist of marginal changes in decisionmaking input, rather than gross changes in decisionmaking output; that most of the benefits can be achieved, perhaps more effectively, through ineans other than board representation; and that costs as well as benefits result. On balance, therefore, the importance of the board's modality function may be considerable as to major shareholders and perhaps creditors, but is questionable as to client and social groups.

\section{Selection and Removal of the Chief Executive; the Monitoring Function}

A fourth cluster of functions served by the board consists of selecting and dismissing the members of the chief executive's office, and momitoring that office's performance. Unlike the advice, authorization, and modality functions, the elements of this fourth cluster are both of critical importance to the corporation and uniquely suited for performance by the board.

\section{Selection}

By law and practice the corporation's chief executive is formally chosen by the board. ${ }^{88}$ Of course, an outgoing clief executive will

87. Id. at 88.

88. In most cases the board also formally chooses other major officers, and often minor officers as well. Both statutes and practice show considerable variation in this regard. As to the major officers (usually president, vice-presidents, treasurer, and secretary), some statutes provide that these officers shall be chosen by the board. See CaI. Corp. Code \& 821 (West 1955); Ill. ANN. Stat. ch. 32, \& 157.43 (Smith.Hurd 1963); N.Y. Bus. CoRP. LAw § 715(a) (McKinney 1963); OHIo Rev. CODE ANN. § 1701.64(A) (Page Supp. 1973); ABA MODEL Bus. CORP. ACT $\$ 50$ (1969 rev.). Others provide that such officers shall be chosen by the board unless otherwise provided by the bylaws, see N.J. STAT. ANN. \$ 14A:6-15(1) (Supp. 1974), or as prescribed by the bylaws or as the board of directors determines, see DEL. CODE ANN. tit. 8, \& 142(b) (Michie 1975). The statutory variations as to minor officers (assistant secretary, assist- 
have a great deal to say in the selection of his successor. ${ }^{89}$ Typically a successor will be sought from within the ranks, and in such cases the outgoing chief executive has far better information on candidates than the board..$^{90}$ Frequently he will have designated a crown prince, either by title (for example, executive vice president), or otherwise; appointment of anyone else is then rendered difficult by the personal and institutional expectations such a designation creates. $^{91}$ And if the chief executive has managed the business well, the board will normally be hesitant to override his judgment as to who can best perpetuate the corporation's prosperity. ${ }^{92}$

Nevertheless, despite significant input from the outgoing chief executive, the board's role in selecting a successor is often considerably more than a formality. ${ }^{93}$ The elements that prevent the board from making business policy, for example, do not prevent it from taking a meaningful role in selection of a new chief executive. Policymaking for a complex enterprise is a full-time occupation; selecting a chief executive is not. Policymaking requires intimate involvement with the business; selecting a chief executive does not. Policymaking depends on a body of substantive knowledge possessed only by those in the field; in the selection of a cilief executive, however, outside directors, who

ant treasurer, etc.) are comparable. Some statutes require that they be chosen by the board. See N.Y. Bus. CoRp. LAW $\$ 715$ (a) (McKinney 1963); OHIO Rev. Code ANN. $\$ 1701.64(A)$ (Page Supp. 1973). Others provide that they shall be chosen by the board unless the bylaws otherwise provide, see N.J. STAT. ANN. \& 14A:6-15(1) (Supp. 1974), or as prescribed in the bylaws, see CaL. CORP. CODE \$ 821 (West 1955); ILl. ANN. STAT. ch. 32, \& 157.43 (Smith-Hurd 1963), or unless the bylaws or certificate otherwise provide, see PA. STAT. ANN. tit. 15, \& 1406 (Supp. 1974), or as p:escribed in the bylaws or by the board, see Dez. CODE ANN. tit. 8, § 142(b) (Mich e 1975); ABA Model Bus. CORP. ACT $\$ 50$ (1969 rev.). Whatever the form, however, the board normally just rubberstamps the chief executive's selections in the case of all officers below the chief executive's level. See Gordon, supra note 3, at 107-08; JURAN \& Louden, supra note 20, at 88, 91-92; M. NewCOMER, THE Big Business Executive 40 (1955).

89. See 1975 CONFERENCE BoARd SURVEY, supra note 10, at 24; GoRDon, supra note 3, at 129 n.21; MACE, supra note 9, at 65-68, 70-71; Heineman, supra note 46, at 159; cf. Zald, Who Shall Rule? A Political Analysis of Succession in a Large Welfare Organization, PAC. SOC. REv., Spring 1965, at 52. An extreme example is recorded by Juran and Louden:

Some [chief executive officers] have resorted to the "sealed letter" method for selecting their successors in an emergency. They have named their successors and the reasons for their choice but have not announced this. Instead, they have recorded it in a sealed letter which is not to be opened unless they meet with some sudden emergency.

JURAN \& LOUDEN, supra note 20 , at 104.

90. See MACE, supra note 9, at 70-71.

91. Cf. Zald, supra note 23 , at 109.

92. Cf. Zald, supra note 89 , at 58-59.

93. See 1975 CONFERENCE BOARD SURvey, supra note 10, at 26; GoRDON, supra note 3, at 107-08; JURAN \& LOUDEN, supra note 20, at 88, 91-92; M. NEwCOMER, supra note 88 , at 40 . 
are themselves often chief executives, ${ }^{94}$ are likely to be as qualified in evaluating candidates as the outgoing chief executive. Thus the board can be expected to and frequently does play a real, albeit restrained role in the selection of a new chief executive.

How important is the selection function? It has been argued that in a large, publicly held corporation the chief executive, or even the top executives taken as a group, cannot determine policy, and that instead this power inheres in the technocrats inhabiting the middle cells of the organization chart. ${ }^{95}$ Although this proposition contains a significant element of truth, it is nevertheless greatly overstated. While it may well be that day-to-day policy can be made only on lower levels, the office of the chief executive (that is, the individual or individuals ${ }^{98}$ who fill that office together, with associated cabinet and staff) will normally be the locus of final decision on most important policies, and will have an indirect voice in other policies through the selection and domination of the other executives. With its large powers over policy, selection, promotion, and budget, that office can do much to determine the profitability and direction of the enterprise; it is, therefore, generally appropriate to give that office credit when the enterprise operates efficiently, and to loold it responsible when the enterprise does not. ${ }^{97}$

\section{Removal and Monitoring}

The removal power is a concomitant of the selection power. In terms of ongoing corporate activities taken as a whole, the selection power is probably the more important of the two. In terms of the special role the board can play, however, the removal power is preeminent-not because removal is so important in itself, but because it subsumes a third, semi-autonomous function: monitoring the results achieved by the chief executive's office to determine whether the incumbent should remain in place A structure which emphasizes the preeminence of this function may be referred to as a monitoring model.

Unlike the received legal model, which, as elaborated, stresses the policymaking function and therefore assumes the board is an integral part of the corporation's management structure, the premise of a monitoring model is that management is a function of the executives, with ultimate responsibility located in the office of the chief executive.

94. See 1973 CONFERence BoARd SuRveY, supra note 14, at 29 Table 5; MACE, supra note 9 , at 87-89.

95. J. GAlBRATTH, THe NEW INDUSTRIAL StATE $59-71$ (2d ed. 1971).

96. See Second Thoughts on the 'Office of the President,' BusiNess WeEk, Oct. 3, 1970, at 42; Vance, Toward a Collegial Office of the President, CALIF. MomT. REv., Fall 1972, at 106; Yunich to Retire at 55 From R. H. Macy, N.Y. Times, Sept. 27, 1972. $\$ 2$, at 63 , col. 5 .

97. Cf. GORDon, supra note 3, at 91-97, 106-15. 
Under a monitoring model, therefore, the role of the board is to hold the executives accountable for adequate results (whether financial, social, or both), while the role of the executives is to determine how to achieve such results. ${ }^{98}$ Of course, the board cannot perform this function without regard to policy: Objectives must be set, explicitly or imphicitly, against which to neasure management's results, and the selection of objectives will partly depend on the directors' broad notions of policy and will interact with the question of what business policies are suitable for the particular firm. Nevertheless, the selection of an objective is distinguishable not only in theory but pretty largely in practice from the determination of how an objective will be met: It is one thing, for example, to demand a certain return on capital; it is another to decide upon the strategy and tactics which promise to yield that return.

The monitoring model, moreover, is not simply nechanistic; monitoring must begin with results, but it cannot end there. Apparently satisfactory profits, for example, may have been purchased by skimping on maimtenance or research, or may flow from a windfall. Similarly, profits which seem unsatisfactory may be the product of an acceptable risk which did not bear fruit, of heavy start-up costs, or of a natural catastrophe. The concept of monitoring for results thus does not preclude the monitors from going behind the result and either accepting as satisfactory a level of perfornance which falls short of the applicable objective, or criticizing as unsatisfactory a level of perfornnance which exceeds it. What the concept of momitoring does require is the availability of sophisticated and independent information-gathering systenis-a matter which will be discussed in Part V-and directors who are equally sophisticated in imterpreting both financial and nonfinancial data.

The critical inportance of monitoring as a board function rests on two elements. First, in the exercise of many of its other functions, including even its power of selection, the board must properly pay great deference to the incumbent chief executive. In the exercise of its monitoring function, however, the board must be completely independent of the chief executive, since he is the very person whose results are being momitored. Second, the very premise of the corporate system, in which control of the factors of production and distribution is vested in the hands of privately appoimted corporate managers, is that it can be expected to attain a nore efficient utilization of economic resources than that achievable under alternative economic constitutions. Given that premise, however, the legal system may and even nuust insist on some structural assurance that such efficiency will be forthcon1-

98. See IRRC, supra note 10, at 16-19. 
ing, and under appropriate conditions the board's monitoring function can he! p provide that assurance.

Since those who manage obviously cannot be trusted to assure their own efficiency, the removal of inefficient managers requires some mechanism external to the managers themselves. One such mechanism is the market in which the corporation operates, with its attendant sanction of corporate failure. But this nechanism permits substantial inefficiency, since given the structure of most markets, a firm can usually remain in business for a protracted period of time if it has even the most meager returns. ${ }^{99}$ A second such mechanism is the takeover bid: If the corporation's assets are inefficiently utilized, its shares will normally be underpriced, tempting outsiders to acquire control through stock purchases. ${ }^{100}$ This mechanism, however, also provides excessive leeway for managerial inefficiency, because of the high transaction costs of takeover bids resulting from their inherent mechamics, ${ }^{101}$ the barriers to success thrown up by the Williams Act, ${ }^{102}$ and the ability of incumbent executives to oppose such bids through use of the target corporation's own resources. ${ }^{103}$ Some further constraint on managerial inefficiency is therefore required to assure the nost efficient utilization of economic resources. An agency that could momitor the efficiency of the chief executive's office on a regular basis, and remove the in-

99. See, e.g., Publicker Industries' Losses on Operations Irk Critics; Firm Manages by Selling Assets, Wall St. J., April 24, 1972, at 30, col. 1.

100. Cf. D. Austin \& J. Fishman, Corporations in Conflict-The Tender OfFER 43.45 (1970); Fleischer \& Mundheim, Colporate Acquisition by Tender Offer, 115 U. PA. L. REv. 317, 324-25 (1967); Hayes \& Taussig, Tactics of Cash Takeover Bids, HARv. Bus. REv., March-April 1967, at 135, 139-40; Manne, Mergers and the Market for Corporate Control, 73 J. PoL. Econ. 110, 112-13 (1965).

101. Cf. O. Williamson, CORporate Control and Business Behavior 99-100 (1970).

102. Pub. L. No. $90-439$, 82 Stat. 454 (1968), 15 U.S.C. $\$ 78 \mathrm{~m}$ (d), (e), $78 \mathrm{n}$ (d)(f) (1970). See Manne, Cash Tender Offers for Shares-A Reply to Chairman Colien, 1967 DUKE L.J. 231.

103. See E. Aranow \& H. Einhorn, Tender OFfers for Corporate Control 219-74 (1973); Schmults \& Kelly, Cash Take-over Bids-Defense Tactics, 23 Bus. LAw. 115 (1967); Note, Defensive Tactics Employed by Incumbent Managements in Contesting Tender Offers, 21 Stan. L. Rev. 1104 (1969); cf. Austin, Tender Offers Revisited: 1968-1972 Comparison with the Past and Future Trends, MERGER \& AcQuislTIONS, Fall 1973, at 16; Hindley, Separation of Ownership and Control in The Modern Corporation, 13 J. LAW \& EcoN. 185 (1970); Armada Pauses on Acquisition Trail to Bolster Own Take-Over Defenses, Wall St. J., June 3, 1974, at 17, col. 1; CNA Financial Corp., Once the Avid Hunter, Now is Worried Prey, Wall St. J., July 22, 1974, at 1, col. 6; Market Place-Obstacles Cited on Take-Overs, N.Y. T:mes, May 28, 1970, at 52, col. 5; Shelters Impede Takeovers, N.Y. Times, Mar. 29, 1970, \$ 3, at 1, col. 1. Cf. Del E. Webb Corp. To Seek Bylaw Chiange on Director Elections, Wall St. J., April 8, 1975, at 14, col. 4; Jorgensen Co. Proposes Dclaware Rechartering as Take-Orer Defense, Wall St. J., April 4, 1975, at 8, col. 5; Instrument Systems Is Asking Its Holders To Make It Even Harder to Oust Directors, Wall St. J., Feb. 24, 1975, at 12, col. 1. 
habitants of that office for inadequate performance, would be ideally suited to aid in the implementation of this critical social function.

Such a power might, of course, be vested in some agency other than the board. But what are the alternatives? The body of shareholders is too disparate, shifting, and clumsy to conduct the type of inquiry involved. Effective replacement would be highly improbable; monitoring in any sense would be all but impossible; and removal situations would be turned into semi-public semi-trials, involving intolerable cost, rigidity, embarrassment, and delay. Assignment of this function to client groups is precluded not only by administrative considerations, but also by the fact that such groups often have special interests which are inconsistent with the general corporate welfare. A council of corporate executives would not present administrative problems, but vesting the power to remove the chief executive in such an organ would put enormous pressure on the chief executive to select subordinates purely on the basis of their subordination. ${ }^{104} \mathrm{~A}$ governmental agency ${ }^{105}$ would almost surely serve to politicize the selection and removal of corporate executives, in the narrowest sense of that terin; ${ }^{100}$

104. This difficulty might be overcome by also vesting such a council with the power to select and dismiss its own members, but divesting the chief executive of those powers would be both impracticable and unwise.

105. See, e.g., Roth, Supervision of Corporate Management: The "Outside" Director and the German Experience, 51 N.C.L. REv. 1369, 1382 (1973); Townsend, supra note 13 , at $69-70$.

106. The history of General Aniline is instructive. In 1942 the U.S. Government took over General Aniline's stock as enemy prcperty, and the Secretary of the Treasury. Henry Morgenthau, who was then in charge of alien property, designated a new president and board. In 1943 Leo Growley was appo'nted Alien-Property Custodian. He forced out Morgenthau's president and half of Morgenthau's board and installed his own designees in their places. In 1947, when Growley's president retired, his successor came to General Aniline through the chairman of the Democratic National Committee. In 1953, when the Republicans came into office, they reappointed only five of 11 outside directors. Only one of these five was a Democrat. Of the six new outside directors appointed by the Republicans, five were Republicans and the sixth was an independent. In 1955 a friend of Eisenhower was named as General Aniline's new president. In 1961, when the Democrats regained office, they ousted all the outside directors except the Democrat the Republicans had left in. Of 15 new outside directors, two were employees of the Justice Department, and the other 13 were either Democrats or independent Kennedy supporters, including the principal lawyer for the Kennedy enterprises, prominent Democratic fund raisers, and an old friend of Joseph Kennedy.

Over the years, similar shifts were made in the position of counsel. During the Truman administration General An:line's general counsel was Steptoe \& Johnson, in which Louis A. Johnson, a prominent Democrat and former Secretary of Defense, was a leading partner. During the Eisenhower administration Steptoe \& Johnson was replaced by Winthrop, Stimson, Putnam \& Roberts, a firm with strong Republican connections. During the Kennedy administrat:on, Winthrop, Stimson was replaced by Manes, Sturim \& Laufer, which was chosen by one of Robert Kennedy's chief assistants who was a longtime friend of one of the fiim's sen'or pa:tners. (The Kennedy administration also dismissed General Aniline's auditors and advertising agency, retaining in their places firms which had connections to the President or Robert Kennedy.) Ross, Gen- 
in any event it is unlikely that any single agency could effectively screen candidates for executive office in hundreds or thousands of corporations, let alone effectively monitor the performance of those it had chosen. Optimal performance of the selection, monitoring, and removal function requires an agency, like the board, which is compact and cohesive, relatively free of conflicting interests, and individualized to the corporation, yet capable of being made independent of executive control.

\section{E. Summary}

A corporate organ comprised in significant part of nonexecutives can rarely either manage the corporation's business or make business policy. It can be useful im providing advice and counsel to the chief executive's office, playing a formal role in the approval of niajor corporate projects, and providing a modality for the exercise of influence and control by nonexecutives, but for the most part these functions are either relatively unimportant or can easily be located elsewhere. There is, however, one cluster of critical functions which such an organ

eral Aniline Goes Private, ForTune, Sept. 1963, at 127, 128-29, 144. See also Schwartz, Governmentally Appointed Directors in a Private Corporation-The Communications Satellite Act of 1962, 79 HARv. L. Rev. 350, $357-61$ (1965) (experience with government-appointed directors on the board of Union-Pacific); Nixon Eyes Fitzsimmons for Meany Comsat Seat, Wall St. J., May 19, 1972, at 5, col. 4 (Frank Fitzsimmons to replace George Meany as a government-appointed director of Comsat, after Meany quit President Nixon's Pay Board while Fitzsimmons stayed on as the Board's only union official).

Government-appointed directors may also raise other problems. For example, they may tend to adopt unduly cautious business policies, cf. Ross, supra, at 148, and may be unduly responsive to presidential jawboning, $c f .1948$ OFFICE OF ALIEN ProperTY ANNUAL REPORT 34-37, to the needs of American foreign policy, cf. 1943 OFFICE of ALIEN PRoperty Custodian ANnUAL Report 67-68, and to challenges to corporate practices issued by government agencies, cf. 1944 OFFICE OF ALIEN ProperTY CusTODIAN ANNUAL REPORT 65-66. These, in turn, are specific instances of a more general problem identified by Professor Vagts:

The effect on a firm of having a partially public management may be compared with that of being subject to regulation. In both cases the tendency of management to maximize profits is subject to restraints designed to further other interests. The restraints imposed by public representatives are not, however, exerted in as plainly visible a fashion and there is less need for the government to take as clear and reasoned a stand. Thus on the one hand there is considerable danger that the government may seek to achieve in the quiet of the conference room what it cannot achieve in the normal administrative process. On the other hand, the asserted tendency of administrative agencies to fall under the influence of the industry they regulate is apt to reveal itself even more with government board members who work together with the regular management and develop a common set of attitudes and a common esprit de corps. On the whole, one is inclined to believe that a more rational and orderly development of econonic law is apt to be achieved by pursuing the American pattern of open regulation rather than the German form of operating through undisclosed negotiations between private and public representatives.

Vagts, supra note 86, at 86-87. See also Schwartz, supra, at 363-64. 
is optimally suited to perform: selecting, momitoring, and removing the members of the chief executive's office. ${ }^{107}$ It therefore follows that the primary objective of the legal rules governing the structure of corporate management should be to ensure effective performance of that cluster of functions-if possible, without precluding the board from playing additional roles if it so chooses. To achieve this objective, these rules must: (1) make the board independent of the executives whose performance is being monitored, and (2) assure adequate and objective information to enable the board to execute its monitoring function. Parts IV and V will explore these requirements in turn.

\section{IV}

\section{The Legal Rules Governing the Composition AND STRUCTURE OF THE BOARD: INDEPENDENCE OF DIRECTORS}

Although the monitoring role of the board is crucial as a theoretical matter, the available evidence admittedly suggests that in practice boards do not perform this function well. Most boards will not remove a chief executive for inefficiency unless the corporation has entered the crisis zone, and cases such as Penn Central, ${ }^{108}$ L-T-V, ${ }^{109}$ Ampex, ${ }^{110}$ and Memorex ${ }^{111}$ indicate that nnany boards will not act until the crisis has become virtually irredeemable. Indeed, outside directors will often resign rather than atteinpt to remove an inefficient management. ${ }^{112}$

One interpretation of this behavior, of course, is that the concept of the monitoring function is an illusion. An alternative interpretation, however, is that effective monitoring has been all but precluded by current corporate ideology and practice. The ideological problem is that the board is commonly conceived as an agency whose primary obligation is not to monitor management, but rather to make policy as an nite-

107. Cf. Bacon, supra note 47, at 44 (remarks of Gustave L. Levy); PoKempner, supra note 79 , at 42 (remarks of John R. Bunting).

108. See J. Daughen \& P. Binzen, The Wreck of the Penn Central (1971); Townsend, Book Review, N.Y. Times, Dec. 12, 1971, \& 6 (Book Review), at 3.

109. See LTV Recounts Its Many Ills, Business WeER, Dec. 19, 1970, at 42.

110. See How Ampex Saturated Recorded Tape Market and Got Soaked Itself, Wall St. J., March 9, 1972, at 1, col. 6; Ampex Corp. Had Loss Totaling \$3.2 Million in Fiscal First Period, Wall St. J., August 23, 1972, at 19, col. 6; Ampex Expects $\$ 40$ Million Loss For Fiscal 1972, Wall St. J., Jan. 12, 1973, at 4, col. 2.

111. Memorex Concedes It's in Financial Morass and That Bank of America Has Intervened, Wall St. J., May 16, 1973, at 4, col. 2.

112. "[F]ar more dangerous than the general ineffectiveness of boards in disaster situations . . . is the lack of any mechanism for identifying and ehminating mediocrity of management. ... . [D]irectors are far more likely to 'go along;' or resign, than to demand changes because of mediocre performance." Heineman, supra note 46, at 157 . See also MACE, supra note 9, at 15, 33-36, 61, 187; Ludlow, The Board of Directors Faces Challenge and Change, Conf. Bd. REc., Feb. 1972, at 39, 41 (remarks of Harleston R. Wood). 
gral part of management. ${ }^{113}$ The problem of corporate practice is that while effective performance of the monitoring function is conditioned on monitors who are (i) independent of those who are monitored, and (ii) capable of obtaining adequate and objective information concerning management, in the case of most boards neither condition is presently fulfilled. First, state corporation law has done little or nothing to insure board independence, and as a result most directors in most publicly held corporations are closely tied to the chief executiveeither economically, through an employment, professional, consulting, or supplier relationship with the corporation, ${ }^{114}$ or psychologically, through friendship, prior employment, or the fact that they have been selected and indoctrinated by the chief executive and hold their seats at his pleasure. ${ }^{115}$ Second, most boards have had no independent mechanism for obtaining adequate and objective information. Instead, directors are almost wholly dependent for information either on the very executives whose performance the information is supposed to reflect, or on accountants who are themselves dependent on those executives. ${ }^{116}$ Although it may be that even independent and fully-inforined boards cannot be expected to perform a monitoring function, ${ }^{117}$ that proposition cannot be established on the basis of the existing record.

If the monitoring function is to be effectively performed, then, the first task of the legal rules goverming the composition of the board inust be to ensure that it is independent of management. The problem is how to achieve that independence consistent with the best effectuation of the monitoring function and, to the extent possible, the board's remaining functions as well. At least three alternative models must be considered: (1) a single-board system in which all directors are required to be independent of management; (2) a single-board system in which independent directors constitute a clear majority; and (3) a dual-board or two-tier system in which managers and supervisors are members of separate corporate organs.

\section{A. A Single Board Comprised Wholly of Independent Directors}

Assuming that the present single-board system is retained, the advantages of requiring all directors to be independent are obvious. Since the board's principal function is to monitor management's per-

113. Cf. Heidrick \& StRuggles, supra note 12, at 5 .

114. See text accompanying notes $27-33$ supra; cf. JURAN \& LOUDEN, supra note 20 , at 164-70, 203-04; Kilborn, Singer's High-Key Diversification Hits a Sour Note, N.Y. Times, Oct. 24, 1974, at 61, col. 3.

115. See text accompanying notes $34-40$ supra.

116. See text accompanying notes 176.81 infra.

117. Cf. MACE, supra note 9, at 195; Roth, supra note 105, at 1381-82. 
formance, and since a director who is not independent can scarcely be trusted to perform that function, board membership for such persons seems counterproductive. Nor, in nost cases, would exclusion of nonindependent directors hamper the board's performance of its other functions. To the contrary, permitting the corporation's executives to sit on the board is inconsistent with the board's advice-and-counsel function, since the executives are already paid to give advice and counsel in their executive capacity; inconsistent with the authorization function, since the board is usually called upon to authorize only what the executives themselves have proposed; and inconsistent with the modality function, since the purpose of that function is to give nonexecutives a voice in corporate decisionmaking. ${ }^{118}$ Similarly, permitting outside counsel to sit on the board severely compromises his objectivity, since he is then simultaneously attorney and client, ${ }^{119}$ and permitting the corporation's investment banker to sit on the board often gives rise to

118. Cf. MACE, supra note 19, at 119, 126-27. Against this view it has been argued that board membership for executives (i) aids in recruitment; (ii) educates executives in board-level management processes; (iii) enables outside directors to evaluate executives who may eventually be candidates for chief executive; and (iv) ensures the presence at board meetings of persons who can answer questions concerning corporate operations. See MACE, supra note 9, at 111-19 (quoting corporate executives); cf. 1975 CONFERENCE BOARD SURVEY, supra note 10, at 63-65. None of these arguments will withstand analysis. The first and second are essentially circular, for if executives were barred from the board it would be unnecessary to educate them to board-level processes, and directorships would cease to be a part of the recruitment apparatus. Additionally, the second rests on the doubtful premise that there is such a tbing as board-level management. The premise behind the third is similarly dubious. Where promotion is from within, as it usually is, the recoinmendation of the outgoing chief executive, rather than the casual evaluations of outside directors, will normally be dispositive. Furthermore, the board-meeting context may provide "an artificial, synthetic exposure" in which to measure ability. Id. at 117. The fourth supports the presence of executives at board meetings, not their membership.

It is sometimes said that executives will speak out more freely at board meetings if they are members rather than merely invited guests. See id. at 115 (quoting a corporate executive). But on what subjects will they speak out? Certainly they are not going to criticize each other or the chief executive.

"If you watch what happens at board meetings, you will observe that any

questions are asked by outside directors and never by insiders. And it's a little bit like a tennis match-if a questioning outside director is at one end of the board table, and the president is at the other end, the question and response results in all eyes moving in unison to whoever is speaking."

Id. at 119-20 (quoting a corporate executive).

119. See Swain, Impact of Big Business on the Profession: An Answer to Critics of the Modern Bar, 35 A.B.A.J. 89, 170 (1949); Gartner, A Question for Mr. Casey, Wall St. J., March 3, 1971, at 10, col. 3; SEC Head to be Sued for Role as Director of Small Firm in '68-'70, Wall St. J., Jan. 16, 1973, at 1, col. 1; Redcay, Corporate Counsel on His Client's Board of Directors, March 8, 1973 (unpublished paper, copy on file with the California Law Review); cf. Investment Company Act, 15 U.S.C. \$\$ $80 \mathrm{a} \cdot 2(19)$ (A) (iv), (B) (iv) (1970). For data concerning the extent to which counsel for publicly held corporations double as directors, see W. Hudson, OutsiDE Counsel: INSIDE DIRECTOR (1973). 
severe conflict-of-interest problems, ${ }^{120}$ and may impair the corporation's ability to raise capital on the most advantageous terms, since the investment-banking community frequently views such a membership as a territorial signal..$^{121}$

\section{B. A Single Board with a Clear Majority of Independent Directors}

Despite the advantages of a rule mandating complete independence, a rule requiring that only a clear majority of the board be independent would probably be preferable, at least today. First, the former rule would in the minds of inany persons represent an unacceptably sharp break with tradition in a social sector which puts a premium on stability. The latter rule, on the other hand, is already almost within reach. Partly as a result of a policy adopted in the mid-1960's by the New York Stock Exchange, ${ }^{122}$ all but a dozen or so of the 1400 corporations listed on that Exchange already have at least one or two outside directors, ${ }^{123} 94$ percent have at least three, ${ }^{124}$ and half have at least seven. ${ }^{125}$ Similarly, nonemployee directors held half or more of the seats in approximately 45 percent of the Fortune 500,50 percent of the industrials in the Heidrick \& Struggles survey, and 70 percent of the

120. See MACE, supra note 9, at 133-34; Slade v. Shearson, Hammill \& Co., [1973. 1974 Transfer Binder] CCH FED. SEC. L. REP. I 94,329 (S.D.N.Y.), question certified, [1973-1974 Transfer Binder] CCH FED. SEC. L. REP. I 94,439 (S.D.N.Y.), interim appeal denied, CCH FED. SEC. L. REP. ๆ 94,914 (2d Cir. Dec. 16, 1974); Black v. Shearson, Hammill \& Co., 266 Cal. App, 2d 362, 72 Cal. Rptr. 157 (1st Dist. 1968).

121. See MACE, supra note 9, at 132, 144-48; cf. JURAN \& LoUDEN, supra note 20, at 202. But see MACE, supra note 9, at 148-49; Robertson, The Underwriters Have to Offer Even More, FoRTuNE, Jan. 1973, at 116, 117-18.

122. New York Stock Exchange, Company Manual B-23; New York Stock EXchange, The Corporate Director and the Investing Public 7 (1965). Until recently, the Exchange required two outside directors for newly-listed companies, but it now recommends a minimum of three. NEW YORK STOCK EXCHANOE, RECOMMENDAtIONS aNd COMMENTS ON Financial Reporting to Shareholders and RELated MatTERS 5.6 (1973).

A requirement of two outside directors is statutorily imposed by the new Ontario statute. Ontario Business Corporations Act, ch. 53, § 122(2), [1970] Ont. Rev. Stat. 427-28. The proposed new Canadian Business Corporations law would also require two outside directors for publicly-held corporations. Bill C-29, \& 97(2), House of Commons, 1st Sess., 30th Parl. (Can. 1974). See also Law No. 66-537 of July 24, 1966, on Commercial Companies, Art. 93, [1966] J.O. 6402, [1966] B.L.D. 353 [hereinafter cited as French Commercial Companies Law], translated in $\mathrm{CCH}$, FRENCH LAw oN COMMERCIAL COMPanIES (1971).

123. See Pubiicker Industries' Losses on Operations Irks Critics, Wall St. J., April 24, 1972, at 28, col. 1; VANCE, supra note 46, at 198.

124. New York Stock Exchange, Response to WhItE PAPER Questionnaire Concerning "Recommendations and Comments on Financial Reporting to ShareHOLders AND ReLATEd MATtERs" 1 (1974) [heremafter cited as WHITE PAPER RESPONSE].

125. Id. 
industrials in the Conference Board survey. ${ }^{126}$ Another advantage of a clear-majority rule is that it would not in itself exclude any category of persons from board membership, and therefore would moot arguments that certain types of persons are valuable board members despite their lack of independence. Correspondingly, a clear-majority rule would put much less strain on the statutory definition of independence in the case of persons whose independence is debatable, such as commercial bankers and retired executives. ${ }^{127}$ Finally, permitting a structural overlap between the inanagerial group and the reconstituted board would encourage inanagement to continue to take iniportant issues to the board on at least a pro forma basis-a practice which is extremely desirable since it significantly augments the board's capability for effective monitoring.

But a clear-majority rule would be effective only if two conditions are met. First, the definition of independence must be rigorous. Specifically, any person who is an executive of the corporation, or who has a professional relationship or material business dealings with the corporation, and any close relatives of such persons, must be treated as not independent. ${ }^{128}$ Second, the independent directors inust be inde-

126. See text accompanying notes $25-27$ supra. Of course, many of the directors now classified as "outside" are not really independent. See text accompanying notes 32 34 supra. Therefore, some outside seats would have to be shifted to achieve de jure independence, and other steps would have to be taken to achieve de facto independence. See text accompanying notes 129-30 infra.

127. Compare MACE, supra note 9 , at 123, with id. at 192 and Moscow, supra note 37 , at 11 .

128. It may be that any director proposed by management should also be considered not independent for these purposes. Cf. WHARTON REPORT, supra note 46, at 465 66.

Two important recent cases, SEC v. Mattel, Inc., CCH SEc. REg. REP. \ 94,807 (D.D.C. 1974), and Springer v. Jones, Civ. No. 74-1455-F (C.D. Cal. Nov. 23, 1974), terminated in settlements involving the restructuring of the board to ensure a clear ma. jority of independent directors. The Mattel action was based on violations of the SEC's antifraud and corporate-reporting requirements. A consent decree required Mattel to appoint additional unaffiliated directors, who are approved by the SEC and the court, in sufficient number to constitute a majority of the board. Mattel also agreed to maintain an executive committee consisting of three or more members, "a majority of whom shall at all times consist of additional directors." For other provisions of the decree see note 217, infra. See also Mattel Posts 27\% Drop in Earnings and Adds. Seven to Its Board, Wall St. J., Dec. 17, 1974, at 6, col. 2.

Springer v. Jones was a derivative action against officers of Northrop Corporation based on illegal political contributions, and a class action against Northrup itself based on violations of the proxy rules. The settlement requires a number of important changes in Northrop's board. First, the size of the board must be increased by the addition of four new dircctors, who are to be approved by the court as qualified in terms of experience, independence, integrity, and ability. Second, 60 percent of the board must consist of "Independent Outside Directors," defined to mean "any person who (i) is not an officer of the Company; (ii) has not individually received from the Company in any of the preceding four ... y years or is not presently proposed to receive in the next year 
pendent in fact as well as in form, and must have effective power to select and remove the members of the chief executive's office.

These two objectives can be achieved only if the board's control of the corporate proxy machinery-that is, the power to nominate directors on the board's behalf and to spend corporate funds and devote corporate facilities toward the election of such nominees-is vested exclusively in the independent directors as a group. ${ }^{129}$ Since control of the proxy machinery carries the de facto power to select and dismiss nembers of the board, who in turn have the power to select and dismiss the executives, whoever has that control has ultimate control over the corporation. At present, the power to select and dismiss directors is typically vested in the chief executive. Since the full board has control of the proxy machinery, and since the chief executive usually dominates at least a majority of the board, he can effectively remove any single board member who opposes him by wielding his power over the board majority to prevent that director's renomination. A director who would otherwise oppose the chief executive will therefore normally either remain silent or resign, unless he can somehow himself mobilize a majority cabal, which is rarely possible. As a result, the external sources of the chief executive's dominance over individual directors, whether economic or psychological, are reinforced by internal political realities, which in turn reinforce his economic and psychological domiv nance. In order to break this circle it is necessary not only to strike at the externals, by ensuring that a majority of the board is not economically tied to the chief executive, but to recast the internal realities as well. Vesting control of the corporate proxy machinery in the inde-

in excess of $\$ 25,000$ (other than fees as a director) for services rendered or from the sale of material; and (iii) is not associated with a company or firm which has in any of the four . . . preceding years received or is not presently proposed to receive in the next year in excess of one percentum . . . of its gross sales from transactions with the Company." The four new directors are specifically required to meet this test. In addition, no lawyer who serves as (or is associated with a law firm serving as) outside counsel to Northrop can be a director. Finally, Northrop must reconstitute its executive committee so that seven of its eight members, including its chairman, are independent outside directors, as defined. For additional provisions of the decree, see notes 130, 217 \& 230, infra.

As a matter of full disclosure: The plaintiff in Springer $v$. Jones was represented by the Center for Law in the Public Interest, a public interest law firm in Los Angeles. I served as a consultant to the Center in connection with that action.

129. See Conard, A Behavioral Analysis of Directors' Liability for Negligence, 1972 DUKe L.J. 895, 917-18; cf. Comment, Duties of the Independent Director in OpenEnd Mutual Funds, 70 Mich. L. REv. 696, 724 (1972).

Some investment companies have already begun on an informal basis to follow similar practices in selecting outside directors. See Glazer, A Study of Mutual Fund Complexes, 119 U. PA. L. REv. 205, 234-35 (1970); Nutt, supra note 13, at 216. However, since the arrangement is voluntary, and the independent directors need only make up 40 percent of such boards, see note 46 supra, the practice stops considerably short of what is necessary to vest control of the board in independent directors. 
pendent directors would facilitate their structural and psychological independence by locating the source of their appointment and the power of their removal elsewhere than in the chief executive. Only so can the momitoring function be made fully effective..$^{130}$

\section{The Two-Tier System}

A third alternative remains to be considered: the dual-board or two-tier system, in which the functions supposedly performed by the single board under the received legal model are distributed between two corporate organs, one entrusted with management and the other with supervision. Originating in Gerinany in the second half of the nineteenth century, ${ }^{131}$ the two-tier systein has been spreading throughout Europe in recent years. The Netherlands has already adopted a variant, ${ }^{132}$ Belgium and Luxembourg are expected to do so, ${ }^{133}$ and France has permitted use of the system on an optional basis since 1966. ${ }^{134}$ In addition, the system is embodied in the present draft of

130. As part of the settlement of Springer v. Jones, see note 128 supra, Northrop Corporation agreed to create a board nominating committee, consisting entirely of independent directors, which "shall nominate all candidates for directors on the Board's behalf; shall cause the names of those candidates to be listed in the proxy inaterials of this Corporation prepared in connection with any meeting at which directors are to be elected; shall be empowered to expend corporate funds to support those candidacies, to the extent permitted by law; and shall appoint the persons who shall serve as proxies to vote the proxies solicited by management . . ." Civ. No. 74-1455-F (C.D. Cal. Nov. 23, 1974).

The technique of treating independent directors as a separate corporate organ for certain purposes also finds precedent in the Investunent Company Act, which provides that certain types of matters require approval by a majority of the independent directors, rather than a majority of the board. See 15 U.S.C. $\$ 80$ a-15(c) (1970) (contracts between the fund and an investment adviser or principal underwriter); 15 U.S.C. \& 80a31 (a) (1970) (retention of accountant).

Probably the law should also require the chairman of the board to be an independent director, since this position provides a potential focal point for leadership of the board, not only because of the title, but also through the power to call, set the agenda for, and chair board meetings. Cf. 1975 CONFERENCE BOARD SURVEY, supra note 10, at 25-26.

131. Conard, Compuny Laws of the European Communities from an American Viewpoint, in THE HARMONISATION of EuRopean COMPANY LAW 45, 52 (C. Schmitthoff ed. 1973); Vagts, supra note 86, at 50-51.

132. Sanders, The Reform of Dutch Company Law, in The HaRmonisation of European Company Iaw 133, 134-35 (C. Schmitthoff ed. 1973); Van De Ven, Corporate Developments in the Netherlands, 27 Bus. Law, 873, 875-77 (1972).

133. See E. Stein, Harmonisation of European Company Laws 154 (1971); Conard, Mace, Blough, \& Gibson, Functions of Directors Under the Existing System, 27 Bus. Law., Feb. 1972, at 23, 25 (special issue).

134. French Commercial Companies Law, supra note 122, Arts $118-50$.

Of 3443 French corporations organized in 1968 and the first half of 1969 , only 42 chose the new two-tier form. Approximately 260 corporations already in existence also adopted the new form. E. STEIN, supra note 133, at 124-25. For a discussion of some of the differences between the French and German systems, see Will, Recent Modifica. 
the proposed European Stock Corporation Law, ${ }^{185}$ and is presently reflected in the proposed Fifth Directive for the Harmonization of Company Law of the Member States of the European Economic Community. ${ }^{188}$

While details vary, the German version may be regarded as prototypical. Under that version, in virtually all stock corporations and in the larger limited liability companies, direct control of the corporate enterprise is vested in an organ known as the Vorstand, or managing board, ${ }^{137}$ which is comprised of the corporation's top executives. The managing board, in turn, is supervised by a second organ known as the Aufsichtsrat, or supervisory board, ${ }^{138}$ which cannot include any members of the managing board. ${ }^{138}$ The supervisory board can adopt rules requiring its approval for specific types of transactions, but is not otherwise empowered to involve itself in the management of the corporation, ${ }^{140}$ and exercises only indirect control over the managing board. It appoints the members of the managing board for periods not exceeding five years and may revoke such appointments for substantial cause, such as gross breach of duty or inabihty to conduct the corporation's business properly; it can express disapproval of the

tions in the French Law of Commercial Companies, 18 INT'L \& CoMP. L.Q. 980, 98891 (1969).

135. Proposed Statute for the European Company, Arts. 62-79, 13 Journaz OrfiCIEL DES COMMUNautés EUROPÉnNNes, No. C 124, at 14-18 (Oct. 10, 1970), translated in Bull. European Communtmes, Aug. 1970, Supp., at 55-68. See Sanders, Structure and Progress of the European Company, in THE HARMONISATION OF EUROPEAN COMPANY LAW 83, 89-96 (C. Schmitthoff ed. 1973); Vagts \& Welde, The Societas Europaea: A Future Option for U.S. Corporations?, 29 Bus. LAw. 823, $825-27$ (1974).

136. The Commission draft would have made a two-tier system mandatory. Proposal for a Fifth Directive on the Structure of the Company, 15 Journal Ofriciel Des Communattes Europeennes, No. C 131, at 49 (Dec. 13, 1972), translated in Bull. EUROPEAN Commenntries, Oct. 1972, Supp. However, an opinion of the Economic and Social Committee of the European Parliament, rendered at the request of the Council, recoinmends that it be optional. 17 OfFiciaz J. European Communities, No. C109, at 9, 10-11 (Dec. 21, 1974). See generally Fieker, The EEC Directives on Company Law Harmonisation, in The HaRmonisation of European Company Law 66, 80-81 (C. Schmitthoff ed. 1973).

137. See Law of Sept. 6, 1965, [1965] BGB1. I 1089, $\$ \S 76-94$ [hereinafter cited as Aktiengesetz], translated in CCH, GERMAN STOCK CORPORATION ACT (F. Juenger and L. Schmidt transl. 1967). See generally Rotl, supra note 105; Schoenbaum \& Lieser, Reform of the Structure of the American Corporation: The "Two-Tier" Board Model, 62 Kx. L.J. 91, at 95-108 (1973); Vagts, supra note 86, at 48-64.

The two-tier system is mandatory for virtually any "Aktiengesellschaft" (roughly speaking, a publicly-held corporation), and any "Gesellschaft mit beschränkter Haftung" (roughly speaking, a close corporation) with over 500 or more employees. Juenger, Introduction to CCH, German Stock Corporation ACT at 1, 2-4 (1967); Schoenbaum \& Lieser, supra, at 98; Vagts, supra note 86, at 32-35.

138. Aktiengesetz $\$ \S 95-116$.

139. Id. \$ 105.

140. Id. \& $111(4)$. 
managing board in its comments to the shareholders on the results of the annual audit; and it can call a special shareholders' meeting to consider the appointunent of special auditors to investigate the managing board's conduct of the business. ${ }^{141}$

Within the last few years there has been much discussion whether the two-tier system should be adopted in the United States. ${ }^{142}$ Certainly such a system would be preferable to the present working model, but it would probably not be preferable to a requirement that the board have a clear majority of independent directors vested with control of the proxy machinery. To begin with, it must be borne in mind that despite their apparently great dissimilarity, most of the differences between the single-board and two-tier systems tend to be marginal. In fact, many or most large American corporations have already adopted working structures strikingly similar to the two-tier system.

141. Id. $\S \S 84(1), 84(3), 111(3), 142(1), 171(2)$.

142. See, e.g., Cary \& Harris, supra note 46 , at 66 (remarks of Professor Cary); Schoenbaum \& Lieser, supra note 137 . Although such a system is not required under the laws of any state, it might be permissible under some of the more recent state corporations statutes. For example, the Delaware code provides:

The business and affairs of every corporation ... shall be managed by or under the direction of a board of directors, except as may be otherwise provided . . . in its certificate of incorporation. If any such provision is made in the certificate ... the powers and duties conferred or imposed upon the board of directors by this chapter shall be exercised or performed to such extent and by such person or persons as shall be provided in the certificate . . . .

Dez. Code ANN. tit. 8, § 141(a) (Michie Supp. 1974). See also ARIz. Rev. Stat. AnN. §§ 10-122, 10-191 (1956); Wisc. STAT. ANN. $\$ 180.30$ (Supp. 1974); ABA MoDEL Bus. CoRP. ACT $\S 35$ (1969 rev.); cf. N.J. STAT. ANN. §§ 14A:6-1, 14A:2-7 (1969); N. LATTin, supra note 2, at 242-43. Professor Ernest Folk, who served as Reporter to the Committee which drafted the 1967 revision of the Delaware statute, has commented that "the Delaware corporation enjoys the broadest grant of power in the English-speaking world to establish the most appropriate internal organization and structure for the enterprise." E. Folz, Amendments to the Delaware Corporation law 5 (Corp. Serv. Co. 1969).

Under the more traditional corporate statutes, however, a full-scale two-tier board would probably be impermissible. These statutes typically provide that the board of directors shall manage the business of the corporation, see text accompanying note 1 , supra, and a formalized and permanent delegation of that power to a second corporate organ would in all likelihood be deemed invalid. See Jackson v. Hooper, 76 N.J. Eq. 592, 603, 75 A. 568, 573 (Ct. Err. \& App. 1910); Long Park, Inc. v. Trenton-New Brunswick Theatres Co., 297 N.Y. 174, 77 N.E.2d 633 (1948); Continental Securities Co. v. Belmont, 206 N.Y. 7, 16, 99 N.E. 138, 141 (1912).

The rationale for this view has been stated as follows: "The State, granting to individuals the privilege of limiting their individual liabilities for business debts by forming themselves into an entity separate and distinct from the persons who own it, demands in turn that the entity take a prescribed form and conduct itself, procedurally, according to fixed rules." Benintendi v. Kenton Hotel, 294 N.Y. 112, 118, 60 N.E.2d 829, 831 (1945). But see Kessler, The Statutory Requirement of a Board of Directors: A Corporate Anachronism, 27 U. CHI. L. REv. 696 (1960).

The English cases reach a sim lar result, although it is based on a contractual rather than a statutory theory. See Wedderburn, The Relationship of Management and Shareholders in the English Company, in Evolution eT PERSPECTIVES Du DRoIT Des

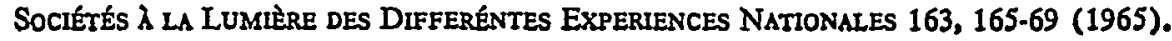


In one such structure, authority for direction and control of the enterprise is vested in a formally constituted general management committee consisting of top executives; ${ }^{143}$ like the German managing board, this committee "determines operating pohcies and objectives and concentrates upon the broad direction, coordination and control of the business as a whole." ${ }^{144}$ It has been said of corporations utilizing such committees that they "have in effect two boards: an inside working board and an outside board of review."145 In this type of structure, however, the "outside" board of review is likely to be dominated by members of the inside working board.

A second (and overlapping) type of working structure, in which the board of review is not likely to be dominated by the working managers, is found in the decentralized corporation. In a centralized corporation the corporate business is departmentalized on the basis of functions, such as production, marketing, and engineering. Since each department constitutes only a fragment of a business, there are frequently no ready criteria by which to judge a department's performance-certainly not profitability. Headquarters in such corporations typically consists of a central office comprised of the president and the chiefs of each functional department; it is therefore responsible both for the coordination of corporate operations and for the determination of overall corporate strategy. In contrast, in a decentralized corporation the corporate business is divisionalized on the basis of product or geography, and each division includes a substantially complete set of functional departments. The performance of each division (and of its general manager) can therefore be measured by profit criteria and, within the constraints of corporate policies and capital funding set by corporate headquarters, the divisional manager can be given substantial autonomy, at least if divisional profits and inarket share meet expectations. Headquarters in such cases typically consists of a general office comprised of executives who are reheved of responsibility for operations and functional coordination. Instead, they are charged solely with setting general corporate policy, making strategic corporate decisions, and allocating corporate resources among the operating divisions. The general office exerts control not by directing operations, as does the central office in the centralized corporation, but through budgetary and ac-

143. See Gordon, supra note 3, at 100-03; P. Holden, C. Pederson \& G. GerMaNe, Top MANagement 71-72 (1968) [hereinafter cited as Top Management]; HoLDEN, Fist \& SMITH, supra note 10, at 24-26; MAURER, supra note 3, at 201, 207-17.

144. HOLDEN, FISH \& SMITH, supra note 10, at 24.

Many corporations have adopted a variant of this concept, in which a formally constituted management council serves principally as a communicative rather than a policymaking device. See Top MANAGEMENT, supra note 143, at 72-73; cf. HoldEN, Fish \& SMITH, supra, at 22-24.

145. MAURER, supra note 3, at 201. 
counting processes, selection and promotion of personnel, and the establishment and interpretation of corporation-wide principles. ${ }^{148}$ In such corporations each division manager is a counterpart to the chief executive in the received legal model of the corporation, while the general office is a counterpart to the board:

The top executive group becomes an "activated board of directors" whether or not they are the legally constituted board. . . . Such an executive group ... does not "manage" in the usual sense of the word . . . . Instead the role of such a group is more like that of an investment manager with the power to choose the particular users of funds . . . and to judge performance of those whom it authorizes to use the capital. ${ }^{147}$

146. American Institute of Management, Corporate Structure In the BusiNESS ENTERPRISE 121-51 (rev. ed. 1961); A.D. Chandler, Strategy aNd STRUCtURE 10. 15, 43-50, 382-89 (Anchor ed. 1966); O. Williamson, Corporate Control aNd BusiNESS BeHAVtor 18-19, 46-49, 113-19, 124-27 (1970); Chandler \& Redlich, Recent Developments in American Business Administration and Their Conceptualization, Bus. Hist. Rev., Spring 1961, at 1, 4-20; Heflebower, Observations on Decentralization in Large Enterprises, J. IND. EcoN., Nov. 1960, at 7.

The decentralized corporation has been described as follows:

Each division is equipped with a self-contained organization having complete jurisdiction over manufacture, sales, and finance, subject to control from the central authority. The ordinary, everyday questions of policy, embodying even such important matters as production schedules, inventory commitments, design of product, and methods of distribution, are left ordmarily within the consideration and decision of the divisions themselves, under certain general limitations, and in every way the men on the firing line are inspired with a sense of responsibility for results.

Brown, Pricing Policy in Relation to Financial Control, 7 MAN. \& AD. 195 (1974).

147. Heflebower, supra note 146 , at 18 . Williamson wrote of the decentralized corporation:

The relationship of the headquarters unit to the operating divisions appears to be largely one where operating divisions are free to conduct their affairs with. out interference as long as they achieve a certain 'objective' profit goal. This relationship is thus similar to the one that exists between the stockholders and the firm. There are, however, major differences that should be noted. First, the headquarters unit has access to vastly more information than the stockholders and hence is able to make a more exacting appraisal. Second, the machinery for replacing a division head is considerably simpler than that for replacing the company president. In both respects, the division is subject to greater pressure than is the firm.

O. Williamson, The ECONOMics of Discretionary Behavior 120 (1964); cf. J. Bower, Managing the Resource Allocation Process 293 (1970).

The resemblance between these working structures and a formal two-tier board is often heightened by constituting the members of the general management committee or general office as the board's executive committee. See BROWN \& SMITH, supra note 10, at 28-30, 94-96; GORDON, supra note 3, at 103-04; HoldEN, FisH \& SMTTH, supra note 10, at 229; TOP MANAGEMENT, supra note 143, at 72; Mylander, Management by Executive Committee, HaRv. Bus. REv., May-June 1955, at 51. Of 508 manufacturing corporations surveyed by the Conference Board, 377 had executive committees; of these, 24 percent were composed entirely of insiders. See 1973 CONFERENCE BOARD SURVEY, supra note 14, at 55-56 Tables 14, 15. Under modern statutes, such a committee can be vested with extensive powers. For example, the Model Act permits such a committee to exercise all the authority of the board except as to certificate and bylaw amendment, 
The major advantage of the two-tier system, therefore, is not that it creates two levels of administration where only one existed before, or that it recognizes management as a separate corporate organ, but that it achieves the separation of those who manage from those who monitor in a particularly sharp manner, ${ }^{148}$ and therefore results in extreme organizational transparancy. ${ }^{14 \theta}$ Separation and transparancy, however, can both be achieved even without a two-tier system: the former, by requiring a clear independent majority and by vesting control of the corporate proxy machinery in the outside directors to ensure their structural and psychological independence from the chief executive; the latter, by making clear that the board can function as a momitoring rather than a managing organ ${ }^{180}$ and by constituting the independent directors as a separate corporate organ for certain purposes, such as control over the proxy machinery. ${ }^{181}$

merger, sale of substantially all assets, and dissolution. ABA MODEL Bus. Corp. ACr \& 42 (1969 rev.). In such cases, therefore, the general management committee or general office is, like the German managing board, a formally constituted corporate organ vested with both factual and legal power to manage the corporation's business. $C f$. L. Gower, Principles of Modern Company LaW 141 (3d ed. K. Wedderburn, 0. Weaver \& A. Park 1969).

148. Under German law and practice, this separation is far from complete. German law bars members of the managing board from serving on the supervisory board, but does not bar other executives from serving on the supervisory board. Cf. Roth, supra note 105 , at 1380 . Furthermore, it is common for banks to be represented, sometimes heavily, on the supervisory board, and the managing board may have leverage over those banking members as a result of competition between banks for corporate accounts. See note 153 infra.

149. See Will, supra note 134, at 991; cf. Vagts, The European System, 27 Bus. LAW., Feb. 1972, at 165, 166 (special issue); Riger, Book Review, 60 GEo. L.J. 859 (1972).

150. For example, under the 1974 amendments to the Delaware corporation law, "[t]he business and affairs of every corporation . . . shall be managed by or under the direction of a board of directors." DEL. CODE ANM. tit. 8, \$ 141(a) (Michie Supp. 1974) (emphasis added). Similarly the Ontario statute provides: "[T]he board of directors shall manage or supervise the management of the affairs and business of the corporation." Ontario Business Corporations Act, ch. 53, \& 132(1), [1970] Ont. Rev. Stat. 430 (emphasis added); cf. ABA MODEl Bus. CORP. ACT \& 35 (1974 rev.).

151. A corollary advantage of the two-tier system is that the sharp legal allocation of roles in the two-tier system helps assure that substantive rules of corporation law are based on accurate premises as to the roles of executives and directors, but this advantage too is only marginal, since even without this sharp allocation enough is now known about corporate life to enable American legal institutions to mold corporate rules on the basis of corporate reality. For example, the courts could even now readjust concepts of off'cers' authority to be more reflective of the truths of corporate life. See, e.g., Lee v. Jenkins Bros., 268 F.2d 357, $365-71$ (2d Cir.), cert. denied, 361 U.S. 913 (1959); Gronholz v. Saginaw Sav. \& Loan Ass'n, 41 Mich. App. 735, 201 N.W.2d 98 (1972); Holman-O.D. Baker Co. v. Pre-Design, Inc., 104 N.H. 116, 179 A.2d 454 (1962); Yucca Mining \& Petrol. Co. v. Howard C. Phillips Oil Co., 69 N.M. 281, 365 P.2d 925 (1961). Similarly, courts could adopt separate standards of care for executive and nonexecutive directors. See, e.g., Bates v. Dresser, 251 U.S. 524 (1920); Boulecault v. Oriel Glass Co., 283 Mo. 237, 223 S.W. 423 (1920); Cary \& Harris, supra note 46, at 64-65; Folk, Civil Liabilities under the Federal Securities Acts: The BarChris Case, 55 VA. L. REv. 
On the negative side, we know very little about the effect of the two-tier system as a structural abstraction. The working of the system in Germany, the only country in which it has an established track history, is integrally related to the German social and economic context. For example, the number of large national commercial banks is relatively small, so that each is very powerful, and because most corporate stock is held in bearer form and deposited with the banks for safekeeping, proxies for a great proportion of the voting stock are in the bankers' hands. ${ }^{152}$ Bankers who sit on the supervisory board therefore often carry enormous weight, and their presence helps assure the independence of many supervisory boards. ${ }^{153}$ Again, the German two-tier system is intimately related to the primciple of codetermination, under whicl labor is formally represented at the board level. Adoption of the two-tier system in the very different American economic setting might produce results very different from those hoped for. ${ }^{154}$

A second problem with the two-tier system as compared to a reconstituted board is that the former would represent a radical break with present institutional practices, while the latter would not. The tradition of the American corporation is that important busimess decisions come before the board, even if only by way of post hoc review. Reconstituting the simgle board would be unlikely to impede this practice, particularly if the reconstituted board includes insiders. In contrast, the creation of a wholly new institution im which mana-

1, 46 (1969); Israels, $A$ New Look at Corporate Directorships, 24 Bus. LAw. 727 (1969); cf. Lanza v. Drexel \& Co., 479 F.2d 1277 (2d Cir. 1973); Feit v. Leasco Data Processing Equip. Corp., 332 F. Supp. 544, 576-78 (E.D.N.Y. 1971); Escott v. BarChris Constr. Corp., 283 F. Supp. 643 (S.D.N.Y. 1968); Bennett v. Propp, 41 Del. Ch. 14, 187 A.2d 405 (Sup. Ct. 1962).

152. See Roth, supra note 105, at 1378-79; Vagts, The European System, 27 Bus. Lsw., Feb. 1972, at 165, 169 (special issue); Petrodollar Pressure on Big Three German Banks, N.Y. Times, Jan. 24, 1975, at 41, col. 1.

153. The extent of the bankers' influence may vary substantially according to the financial strength of the corporation, since the management of a strong corporation which does business with several banks may be able to neutralize them by playing one off against the other, or by threatening to shift the corporation's business entirely. $C f$. Roth, supra note 105 , at 108.

154. Putting these questions aside, a reconstituted single board might have several distinct advantages over the specific two-tier system adopted in Germany. For example, under American law managers can normally be discharged from their positions without cause. Under the German two-tier system, however, the meunbers of the managing board cannot be discharged during their term (which may run up to five years) except for "wichtiger Grund"--substantial cause. See Aktiengesetz, supra note 137, § 81; Schoenbaum \& Lieser, supra note 137 , at $95-96$. The German system therefore gives management a security of tenure which tends to defeat one of the very purposes the separation of managers and monitors should be designed to achieve. Again, under American law the intra-executive structure can be made to vary according to the needs of the individual business. Under the German two-tier system, however, a formal collegial structure is imposed on the top executives whether or not it is suitable to the needs of the business. See Aktiengesetz, supra note 137, \$ 77(1). 
gers and monitors did not mix might well result in cutting off the flow of business decisions to the outside board on an ongoing basis, thereby reducing that board's capacity to gain the feel for the corporate situation which helps bring the financial data to life. The net result of adopting a two-tier systein in this country might therefore actually be a weakening of the crucial monitoring function, as compared with the results achievable through a reconstituted single board.

\section{V}

\section{ThE FLOW OF INFORMATION TO THE BOARD AND THE ROLE OF THE ACCOUNTANT}

To the extent that the autonomy of corporate management ultimately rests on notions of efficiency, and to the extent that the board's nrajor role is to nonitor management, the institutions by which managerial efficiency is measured-whether by the board or by othersnust be a central concern of the corporate system. As a practical matter, such institutions must have three interrelated characteristics: (1) the indexes they employ must be numerical in nature; (2) the numbers they generate must be coniparable with those generated in measuring the efficiency of management in like enterprises; and (3) the methods by which the numbers are generated nuust be as objective as possible. The primary techniques used today to measure managerial efficiency center on indexes involving corporate profits. Such indexes obviously meet the first qualification: they are nothing if not numerical. It is widely recognized, however, that the profits of a corporate enterprise can never be determined with complete objectivity and comparability, since they are in significant part a function of the choice of accounting principles employed in the preparation of its financial statements. ${ }^{165}$ In theory, a satisfactory degree of objectivity and comparability is nevertheless achieved through institutional means-the central role given to independent accountants. In practice the theory has not held

155. See Arthur Andersen \& Co., Establishuno Accountino Prunciples-A CRISIS in Decision Making 1-2 (1965) [hereinafter cited as CRISIS]; P. GradY, INVentory of Generaliy ACCepted ACCOUNTINg Principles for Business ENTERPRISEs 33-34, 373-97 (AICPA Accounting Research Study No. 7, 1965) [hereinafter cited as GRADY]; Graham, Some Observations on the Nature of Income, Generally Accepted Accounting Principles, and Financial Reporting, 30 LAW \& CoNTEMP. ProB. 652, 669-72 (1965); Even Accountants Find Some Financial Reports of Combines Baffling, Wall St. J., Aug. 5, 1968, at 1, col. 6; Were 'Golden Fleece' Earnings Per Share \$3.14 or \$1.99? Well . . . , Wall St. J., Aug. 5, 1968, at 14, col. 3. See generally A. BrulofF, THB EFFectiveness of AcCountino Communication (1967); A. BRILoff, Unaccountable Accountino (1972).

Although this Article will focus on accounting principles, similar observations are applicable to accounting estimates. Cf. Frishkoff, Consistency in Auditing and APB Opinion No. 20, J. Accountancy, August 1972, at 64. 
up, due to a series of institutional failures. First, responsibility for selecting accounting principles has been placed with management rather than with the accountants; second, management has been given enormous discretion in selecting among competing accounting principles; and fimally, the accountants have been dependent upon management for their selection, tenure, and dismissal. If the board is to momitor the efficiency of management in a meaningful way, these failures inust be clearly perceived and effectively remedied.

\section{A. The Failure of the Accountants}

\section{Responsibility for Selecting Accounting Principles}

Since a major purpose of financial statements is to measure management's performance, and since the financial data reported by a corporation depend in significant part on discretionary choices among competing accounting principles, it is reasonable to expect that the principles employed in the preparation of a corporation's financial statements will be selected by the corporation's outside accountant, and not by its managers. ${ }^{158}$ The outside accountant, after all, is a professional, skilled in accounting principles and practice, and presumably objective in the exercise of his discretion. In contrast, the manager typically has no advanced training in accounting and is invariably highly self-interested in selecting those principles that show off his performance in the best possible light. ${ }^{157}$

Yet the official position of the American Institute of Certified Public Accountants is that "the accounts of a company are primarily the responsibility of management. The [only] responsibility of the auditor is to express his opmion concerning the financial statements and to state clearly such explanations, amplifications, disagreement, or disapproval as he deems appropriate."158 To put this differently, the accountants' position is that their role is not to determine which accounting principles most appropriately present the financial results, but only to certify that the primciples selected by management are not completely inappropri-

156. Cf. Letter from E. Feany, J. Aocountancy, April 1967, at 27.

157. Cf. D. Ladd, Contemporary Corporate accounting and the Public 164 (1963) [hereinafter cited as LADD]; Johnson, Management and Accounting Principles, 30 LAW \& CONTEMP. PROB. 690, 693-98, 702-05 (1965); Miller, Audited Statements-Are They Really Management's?, J. Accountancy, Oct. 1964, at 43, 45; Sterling, Accounting Power, J. Accountancy, Jan. 1973, at 61, 65; Kripke, Book Review, 73 Colum. L. REV. 1681, 1686 (1973).

158. AMERICAN INSTitute of Centified Public Accountants [hereinafter referred to as AICPA], Accounting Research and Terminology Bulletins 10 (final ed. 1961) (emphasis added). See also AICPA, Committee on Auditing Procedure, Statement on Auditing STANDARDS $\S 110.02$, at 1-2 (1973) [hereinafter cited as AUDITING STANDARDS] ("Management has the responsibility for adopting sound accounting policies"); GrADY, supra note 155, at 12. 
ate. As an academic accountant has stated: "An analogy might be having the baseball batter calling the balls and the strikes."150

\section{Discretion in Selecting Among Competing Accounting Principles; the Test for Certification}

Placing responsibility for selecting accounting principles with management rather than with the accountants might perhaps be tolerable if management's discretion in selecting among competing accounting principles were relatively circumscribed. But here too reasonable expectations have been confounded. Since the accountant's major control over the financials is his power to withhold or qualify his certification, the test for determining whether a clean certificate will be granted is critical to the integrity of the process. The test the accountants have formulated is whether the financial statements "present fairly the financial position of [the company] and the results of its operations ... in conformity with generally accepted accounting principles . . . ."100 As elaborated and applied this test has been fundamentally defective, because an accounting principle may be "generally accepted" without being fair, and because certification has been deemed permissible even though the corporation's financial statements do not fairly present its financial position and the results of its operations.

a. "Generally accepted accounting principles." It might seem reasonable to expect that the essential standard for certifying the acceptability of an accounting principle would be that the principle presents fairly the transactions it describes. The accountants, lowever, do not so interpret the matter. In their view, a principle can be certified as "generally accepted" merely on the basis of past use in other financial statements or support in the literature. ${ }^{101}$ Since accounting principles are selected by management, however, the test of past use need only mean that a few accountants have agreed not to object to a management decision, ${ }^{162}$ while the test of support in the literature need only mean that a single accountant has published his reasons for not objecting to such a decision. Furthermore, when the significance

159. Horngren, Accounting Principles: Private or Public Sector?, J. Accountancy, May 1972, at 37, 41. See also Johnson, supra note 157, at 698-99.

160. AUdITING Standards, supra note $158, \S 511.04$ at 81 .

The accountants piefer to use the terms "opinion" or "report," rather than "certificate," but the latter is both more meaningful and more prevalent in common usage.

161. See id. $\$ \S 410.03,410.04$ at 71-72; T. FifLIs \& H. KRIPKE, AcCOUNTING FOR BUSINESS LAWYERS 86-87 (1971) [hereinafter cited as FIFLIS \& KRIPKE]; GRADY, supra note 155 , at 52-53; Miller, supra note 157 , at 44.

162. Cf. Audrting Standards, supra note $158, \$ 410.03$ at 71 ("an accounting principle may have only limited usage but still have general acceptance"); Armstrong, Some Thoughts on Substantial Authoritative Support, J. AccovsTancy, April 1969, at 44, 47-48. Armstrong holds that intraoffice memoranda based on discussions inside the firm and with other accountants can constitute "substantial authoritative support" rendering a principle "generally accepted." 
of past use is combined with the power of management to determine what principles are used-subject only to the test of past use by other managements-it follows that an accountant may certify a statement even though he believes that the principles employed in its preparation do not account for the underlying transactions as fairly as competing principles that management has rejected. ${ }^{163}$ This in turn provides further support for the principle, and since managers of competing companies are evaluated by comparing the financial results of their corporations with those of their competitors, there is great pressure for inferior principles to spread throughout an industry. The net result is a frequent tendency toward general deterioration of both accounting principles and financial statements. As one accountant has put it: "[T] his chain reaction . . . leads to a reverse of keeping up with the Joneses; it is a keeping down with the Joneses. As Leonard Spacek has observed, the tendency noted by Gresham's Law, that bad money drives out the good, seems to apply to accounting: The bad alternatives drive out the good alternatives." 164

The rule that "general acceptance" can rest on past use or support in the literature, which is the foundation of this tendency in accountmg, was far from inevitable. Even if individual accountants did not want to render a judgment on the fairness of individual accounting principles-notwithstanding the language of their certification-the AICPA's Accounting Principles Board (APB) was empowered to issue

163. See Briloff, Old Myths and New Realities in Accountancy, 41 AccounTing Rev. 484, 489 \& Table 4 (1966); Hoenemeyer, Compatibility of Auditing and Management Services-II. The Viewpoint of a User of Financial Statements, J. AccouNTANCY, Dec. 1967, at 32, 35; Kripke, Conglomerates and the Moment of Truth in Accounting, 44 Sr. JoHn's L. Rev., Spring 1970, at 791, 794 (special issue); Kripke, Book Review, supra note 157, at 1688; cf. Seidler, Auditors Labor Under Mighty Handicaps, Com. \& Fin. Chron., Jan. 13, 1972, at 1, 18.

164. Miller, supra note 157 , at $44-45$. Another accountant has put it more succinctly: "The developinent and regulation of accounting theory and practice is basically the result of ad hoc expedients, largely dictated by the very corporations whose affairs are being accounted for." LADD, supra note 157, at 160 . "General acceptance . . . tends to mean 'anything goes.' "Id. at 163.

Consider the following statement by a then-member of the APB:

A few weeks ago, I received a telephone call from a practicing certified public accountant who was trying to decide whether he should accept a change in an accounting principle proposed by one of his clients . . . [ [who] had just returned from a convention where a competitor had told how he intended to improve eamings merely by adopting the proposed accounting method. The acceptability of the new method was in doubt.

I asked whether any authoritative support had been found for the proposed principle and he replied, "Well, I looked for an example in Accounting Trends \& Techniques but found none, so, I thought I should give you a call,"

Obviously, he was thanked for the expression of confidence and then I proceeded to comment on his failure to undertake a more thorough search for substantial authoritative support concerning the proposed accounting principle. Armstrong, supra note 162 , at 44. 
authoritative opinions on accounting principles generally. If the principles approved in those opinions had been deemed to preempt competing principles, the criterion of past use might gradually have given way to a criterion of analytical soundness. Unfortunately, the AICPA took just the opposite position:

1. "Generally accepted accounting principles" are those principlies which have substantial authoritative support.

2. Opinions of the Accounting Principles Board constitute "substantial authoritative support."

3. "Substantial authoritative support" can exist for accounting principles that differ from Opinions of the Accounting Principles Board. ${ }^{165}$

Of course, in some cases an APB opimion would either cast grave doubt on some or all competing principles or explicitly render competing principles unacceptable. But simce the APB was practitioner-dominated and notoriously weak, ${ }^{166}$ in many areas it did not speak at all, ${ }^{167}$ in many others it did not speak decisively, and even where it spoke decisively its opmions often failed to drive out unsound accounting practices. ${ }^{168}$

The accountants' rejection of a standard of fairness in the all-toofrequent absence of an authoritative opimion by an organ of the AICPA,

165. AICPA, Disclosure of Departures from Opinions of the Accounting Principles Board (Special Bull. 1964), reprinted in AICPA, OpINIONS OF THE ACcountino PrINCIPLES BOARD 48 (1965) [hereinafter cited as Special Bull.]. In 1972, the APB was replaced by a board which is expected to narrow the choice of competing principles. See text accompanying notes 186-88 infra. On the status accorded APB opinions prior to 1973, see AICPA, Establibhino Financial Accountino Standards $39-43$ (1972) [hereinafter cited as WHEAT REPORT]. On their present status, see text at note 189, infra.

166. See Overhaul of Accounting Rule-Making Unit Expected Today, Is Seen Reducing Conflicts, Wall St. J., May 2, 1972, at 42, col. 1:

"Do [the members of the APB] speak for their clients?" an APB staff member asks rhetorically. "Every once in a while I sit there and I can tell you which client is speaking. It is always big-big. Not only are they speaking for a client. They are speaking for every damn client they have and all the ones they'd like to have."

See also Kripke, The SEC, The Accountants, Some Mytis and Some Realities, 45 N.Y.U.L. REv. 1151, 1184 (1970); Louis, The Accountants Are Changing the Rules, FoRTuNE, June 15, 1968, at 177, 336; Accountants Striking Dry Well in Attempts to Significantly Change Oil-Company Rules, Wall St. J. Feb. 16, 1972, at 32, col. 1; Accountants' Top Rule-Making Body Drops Plan to Limit Pooling-of-Interest Mergers, Wall St. J., Aug. 3, 1970, at 4, col. 2; Accounting Body Fails in Attempts to Change Some Firms Reporting, Wall St. J., Jan. 8, 1968, at 1, col. 6 (Pacific Coast ed.); Metz, Market Place: Debate Lingers on Accountants, N.Y. Times, Jan. 24, 1973, at 52, col. 3; Metz, Market Place: New Accounting for Land Sales, N.Y. Times, Jan. 4,1973 , at 54 , col. 2.

167. Cf. FIFLIS \& KRIPKE, supra note 161 , at 87.

168. See CRISIs, supra note 155, at 9; Cushing, Accountlng Changes: The Impact of APB Opinion No. 20, J. Accountancy, Nov. 1974, at 54, 62; Accounting Panel Seen Curbing Use of Special Items, Wall St. J., March 5, 1973, at 2, col. 2. 
and their readiness to rely on past use as the standard in certifying general acceptability, is well-illustrated by the leading case of Escott $v$. BarChris Construction Corp. ${ }^{169}$ and the critical comment it engendered. In that case, BarChris was engaged in the construction of bowling alleys and had entered into a transaction under which an alley it built for a wholly-owned subsidiary was "sold" to a factor, which then leased the alley back to a second subsidiary whose obligations to the factor were guaranteed by BarChris. Thus the transaction was in substance (and to a large extent in form) a loan by the factor to BarChris on the security of the alley and BarChris's guarantee. In its financial statements, however, BarChris treated the amount it liad received froin the factor as sales income and did not slow the amount owing to the factor as a direct liability. BarChris's accountants-Peat, Marwick, Mitchell \& Co.-certified that the financials were prepared in accordance with generally accepted accounting principles. Obviously, no sound accounting principle would have permitted this transaction to be accounted for as a sale. The cash that changed hands was not the result of an arm's-length price paid by a willing buyer, but simply a loan by a factor engaged in the business of lending, and when all the shooting was over BarChris retained both the use of the property (through its wholly-owned subsidiary) and the econounic risks of ownership (through its guarantee). In a private action against Peat, Marwick and others, brought under section 11 of the Securities Exchange Act by purchasers of BarChris convertible debentures, the certification was accordingly found wanting and hability was imposed on the accountants.

Subsequently, an article published in the Journal of Accountancy criticized this result. The authors did not specifically assert that the accounting treatment of the transaction was fair. Instead they argued, in substance, that in determining whether an accounting principle selected by management is certifiable, fairness is irrelevant:

In BarChris the Court ruled that profits on a sale-leaseback should have been eliminated; however, the AICPA statements on accounting principles at the time of the transaction were silent as to the need for eliminating such profits. . . .

Let us re-examine the BarChris sale-leaseback transaction in the light of then existing accounting principles to answer the claims of some commentators that the relevant principles were sufficiently defined before the case was brought to trial. One might advance several reasons to explain why BarChris should [not have reported profit from the sale-leaseback transaction] .... [T]he overriding doctrine of fairness might be invoked; one might argue profit [from the transaction] should be eliminated so that financial statements

169. 283 F. Supp. 643 (S.D.N.Y. 1968). 
would fairly present the financial position and results of operations for BarChris.

But the doctrine of fairness is necessarily egocentric. He who espouses it presumes to know the one and only correct interpretation of a given transaction. Unfortunately, fairness like beauty exists in the eye of the beholder. What appears fair to one often appears unfair to another. No one denies the propriety of fairness, but accountants need more explicit guidelines. ...

... [R]easonable doubt existed as to what was required in accordance with the generally accepted accounting principles circa 1960. . . 170

Thus the authors' position-which seems to reflect the prevalent attitude of the accounting profession ${ }^{171}$ and indeed the official position of the AICPA-appears to be that an accounting principle can be considered generally accepted if it is in use and has not been specifically disapproved by an authoritative institution, whether or not it fairly accounts for the transaction it describes. That position, however, rests on a fallacious premise-that "[h]e who espouses [a test of fairness] presumes to know the one and only correct interpretation of a given transaction." One need not know the "one and only correct interpretation" of a transaction to know when an interpretation is obviously incorrect. $^{172}$ This is perfectly illustrated by the BarChris case itself, because the possibility that there was inore than one fair way to describe the transaction clearly does not inean it could be accounted for in any way management chose. No one would claim, for example, that the transaction could have been accounted for as a gift, and it was equally inappropriate to account for it as a sale yielding sales income. An argument that accounting for the transaction as a sale was permissible because others were doing it and the APB had not forbidden it simply demonstrates the moral and intellectual poverty of the term "generally accepted accounting principles" as interpreted by the accountants.

b. "Presented fairly." Vesting in management the power to select the principles applied to audit its own performance might perhaps have been made tolerable by narrowly confining management's discretion in selecting among competing principles; ${ }^{178}$ this the accountants failed to do. Alternatively, vesting in management wide discretion to select among competing principles might perhaps have been made tolerable

170. Reiling \& Taussig, Recent Liability Cases-Implications for Accountants, J. Accountancy, Sept. 1970, at 39, 41-42.

171. Cf. Carmichael, What Does the Independent Auditor's Optnion Really Mean?, J. Accountancy, Nov. 1974, at 83, 84; Rosenfield \& Lorensen, Auditors' Responsibilities and the Audit Report, J. Accountancy, Sept. 1974, at 73, 74, 76-77, 82.

172. Cf. Summers, "Good Faith" in General Contract Law and the Sales Provisions of the Uniform Commercial Code, 54 VA. L. Rev. 195, 199-207 (1968).

173. Cf. LADD, supra note 157 , at 163-65. 
by forbidding a clean certificate even though each principle selected by management was generally accepted, if the financial statements taken as $a$ whole failed to present fairly the corporation's financial picture. This interpretation of the accountant's role seems called for by the legitimate expectations of the statement-using public and by the very language of the certificate itself-that the company's financial statements "present fairly . . . in accordance with generally accepted accounting principles" its financial position and operating results. To read this language as satisfied simply because eacli principle employed in the preparation of the financial statements is generally accepted would be to read the tern "fairly" riglit out of the certification: If a statement prepared in accordance with generally accepted accounting principles is presented fairly by virtue of that fact alone, there would be no difference between "present . . . in accordance with" and "present fairly . . . in accordance with."

Once more, however, the accountants have managed to subvert legitimate expectations by interpreting their role in a minimalist way. While the AICPA has failed to give a definitive interpretation of the language in question, many or most accountants take the position that as long as the financials are prepared in accordance with generally accepted accounting principles, certification is proper even if the auditor beheves that the statements are not fairly presented. ${ }^{174}$ The following exchange illustrates the point:

Chairman [of a Practicing Law Institute Panel]: . . . Let us assume that a company has a lot of decisions to make on accounting principles and [that in each case] the company uses a more liberal method or the one that is least acceptable. . . . Do you think that while each of these might have been a generally accepted accounting principle, in the aggregate they can so distort the financial statement that you would not be willing to give an opinion that they fairly present the financial condition of the company?

. . . CPA: I think that is like being a little bit pregnant; there is no such thing. I think what you do in a case like that would be

174. One commentator concluded:

The auditor is not required to state that the principles followed were proper or that, in his opinion, the financial statements give a fair presentation .... [I]t is possible that the individual auditor may actually betieve that the statements are not fairly presented.

Hennessy, Unrealities in Accounting Reporting, in Proceedings of the Etghth ANNuAL INSTITUTE OF ACCOUNTING 12 (1961) quoted in Briloff, Old Myths and New Realities in Accountancy, 41 Accountrivg Rev. 484, 488 (1966). Cf. Carmichael, supra note 171; Rosenfield \& Lorensen, supra note 171, at 73-77. But cf. United States v. Simon, 425 F.2d 796 (2d Cir. 1969), cert. denied, 397 U.S. 1006 (1970), discussed at text accompanying notes 199-205 infra; Kripke, supra note 163, at 793; Casey Warns Accountants of SEC Action If Industry Doesn't Upgrade Standards, Wall St. J., Oct. 3, 1972, at 3 , col. 2. 
to take a deep breath, swallow hard, and sign the certificate. You might try to persuade management that your feeling is that they slould not use all of them because of the danger of creating what might be considered a distortion. Under the present rules of the game, if they insist on doing it, you have no alternative. ${ }^{175}$

\section{The Selection and Dismissal of Accountants}

Virtually the only substantive limit placed on management's discretion by the accountants is that the principles management selects in preparing its financial statements must be "generally accepted."170

175. Quoted in A. Briloff, "For What" and "To Whom" Should Corporate Management and Auditors be Responsible? 7-8, Address before the Financial Executives Institute, Western Regional Conference, June 6, 1970; cf. Carmichael, supra note 171, at 86; Rosenfield \& Lorensen, supra note 171, at 81-82. This interpretation of the accountant's certification was exphicitly rejected by the Second Circuit in United States v. Sinon, 425 F.2d 796 (2d Cir. 1969), cert. denied, 397 U.S. 1006 (1970), discussed at text accompanying notes 199-205, infra. A survey taken by Briloff before Simon disclosed the following interpretations of the phrase:

\begin{tabular}{lll}
\hline \hline & $\begin{array}{c}\text { From the } \\
\text { Financial } \\
\text { Coinmunity }\end{array}$ & $\begin{array}{c}\text { Froin the } \\
\text { Accounting } \\
\text { Profession }\end{array}$ \\
\hline $\begin{array}{l}\text { The clause "present fairly } \text { formity with GAAP" means that in the } \\
\text { auditor's opinion }\end{array}$ & & \\
$\begin{array}{l}\text { The statements are both fair and in } \\
\text { accordance with GAAP }\end{array}$ & $44[\%]$ & $34[\%]$ \\
$\begin{array}{l}\text { The statements are fair because they } \\
\text { are in accordance with GAAP }\end{array}$ & 22 & 30 \\
$\begin{array}{l}\text { The statements are fair only to the } \\
\text { extent that GAAP is fair }\end{array}$ & 28 & 20 \\
None of the foregoing & 6 & 16 \\
\hline
\end{tabular}

Briloff, supra note 163 , at 488 .

176. A further linit is the requirement that the financial statements "present fairly [the position of the company] . . . in conformity with [GAAP] applied on a basis consistent with that of the previous year." AUDITING STANDARDS, supra note 158, \$ 511.04 at 81 (einphasis added). In practice, however, at least until recently, management has been able to switch principles with virtually no constraint. For example, in 1968-69 more than 60 corporations, including many of the largest stcel companies, switched from accelerated to straight-line depreciation for no apparent reason other than to increase reported earnings. Inland Steel raised its reported 1968 income $\$ 17.3$ million by the switch, and U.S. Steel raised its 1968 reported income $\$ 94$ million by this and other switches. Similarly, in 1970-71 a number of corporations changed their inventory accounting method from LIFO to FIFO to raise reported profits, despite the fact that such a switch results in a very substantial increase in taxes. Allegheny Ludlum, for example, increased its taxes for 1970 by $\$ 6$ million through this switch. See FIFLIs \& KRIPKE, supra note 161, at 83, 196, 264; Frishkoff, supra note 155, at 64-65; Frishkoff, Some Recent Trends in Accounting Changes, $8 \mathrm{~J}$. Accounting Res. 141, 142 (1970); Allegheny Ludlum Asks IRS Approval to Switch System of Accounting, Wall St. J., March 4, 1970, at 4, col. 2; Allegheny Ludlum Plan to Change Accounting Draws Holder's Fire, Wall St. J., April 15, 1970, at 15, col. 1; Inland Steel Changes 2 Accounting Methods, Lifting Net 27\%, Wall St. J., Sept. 26, 1968, at 23, col. 1. See also, e.g., First National City Alters Accounting in Chase Race, Wall St. J., Jan. 9, 1969, at 5, col. 3; Metz, Market Place: Swift Net Aided by Accounting, N.Y. Times, Dec. 12, 1972, at 
Virtually the accountant's only mechanism for enforcing this limit is his power to withhold a clean certificate from the corporation's fimancial statements. Yet by law, and largely by practice, the selection, tenure, and dismissal of an accountant is entirely im the hands of the management. Moreover, management is not hesitant to use this power. During the 18-month period of November 1971 to April 1973 there were approximately 400 accountant changes among the corporations which must file Form 8-K's with the SEC, and during the 18-month period of January 1973 to June 1974, there were approximately 700 such changes. At least 10 percent of these changes, and almost certainly more, were made against a background of disputes over accounting principles. ${ }^{177}$

The accountant's dependence on management for his tenure, when combined with management's discretion in selecting among competing accounting principles and the low standards set by the accountants for determining whether a given principles is "generally accepted," result in an almost irresistible pressure on the accountant to go along with marginal principles. ${ }^{178}$ The accountant "can swallow his convic-

\section{0, col. 2.}

In 1971 the APB attempted to tighten up this area with APB Opinion No. 20, but the operational effect of that opinion is not yet clear. See note 185 infra.

177. Hawes, Disclosing Auditor Changes, 7 Rev. SEc. REg. 837 (1974); SEC Securities Act of 1933 Release No. 5534 (Oct. 11, 1974).

Until 1971, it was almost impossible to gather meaningful information on the real reasons for auditor changes. See Now, When Auditors and Clients Split Up After Feud, The Public Must Be Told Why, Wall St. J., Feb. 23, 1972, at 36, col. 1. In 1971, however, the SEC amended its Form 8-K (which requires registered corporations to report specified types of events within ten days after the close of the month in which they occur) to include a new Item 12, calling for (i) a report when a new accountant is engaged, and (ii) a letter

stating whether in the eighteen months preceding such eugagement there were any disagreements with the former principal accountant on any matter of accounting principles or practices, financial statement disciosure, or auditing procedure, which disagreements if not resolved to the satisfaction of the former accountant would have caused him to make reference in connection with his opinion to the subject matter of the disagreement.

The registrant was also required to request the former accountant to furnish a comparabie letter. Even these provisions did not produce entirely reliable information, and recently the 8-K was further amended to broaden the scope of the disclosure and require that the infornation called for in the separate letter be supplied in the 8-K itself. Related amendments were made in Regulation S-X and the Proxy Rules. SEC Securities Act of 1933 Release No. 5550 (Dec. 20, 1974); see Hawes, supra.

178. Mautz and Neuman observe:

One nonofficer director commented to us, "The independent CPA is like a mayor. His first task is to get reelected." He asserted this without any intent of vilifying CPAs. His point was that continuity of the auditor-client relationship is necessarily a matter of importance to the independent CPA and is dependent ultimately on the management of the chent company. He implied that the CPA's awareness of this situation could enter into his relationship with management personnel of client companies in ways so subtle that the CPA had an almost impossible task in guarding against them.

Mautz \& Neumann, The Effective Corporate Audit Committee, HaRv. Bus. Rev., 
tions or he can qualify his opinion, or he can resign. Usually the latter two courses are one and the same.' "179

The pressure on the accountants to go along in inarginal (and even less-than-marginal) cases is considerably augmented by the fact that if an incumbent accountant does balk, a more flexible auditor can almost always be found. ${ }^{180}$ The result is that an accountant who uses or threatens to use his only real control over management's selection of accounting principles is likely to lose his own position without materially benefiting those who use the corporation's financial statements. Many accountants appear to regard the withholding of a clean opinion under such circumstances as a quixotic gesture. ${ }^{181}$

\section{B. Structural Reform of the Accountant's}

\section{Corporate Role}

The accountant plays a critical role in the modern corporation:

Nov.-Dec. 1970 , at 57, 61. See also Kripke, supra note 166, at 1185 . Kripke notes that "[o]ne might suppose that the huge size of the accounting firms (some of them with 4000 or more professionals) would make them independent of even the largest client. But it apparently does not work that way. The thousands of professionals are scattered among numerous local offices, and each office seemingly must show its own profitable operation and keep its clients happy." Id. at 1185 n.146.

179. LADD, supra note 157, at 163-65, quoting Leonard Spacek. See also Sterling, supra note 157, at 61-62, 65; cf. Metz, Market Place: Real and Ideal in C.P.A. Audits, N.Y. Times, Nov. 18, 1972, at 52, col. 3; Why Didn't Auditors Find Something Wrong With Equity Funding?, Wall St. J., May 4, 1973, at 1, col. 6.

180. For example, in late 1971 Boothe Compater Corporation, which was engaged in the business of leasing computers, prepared a financial statement carrying as assets $\$ 2.6$ billion in IBM System 360 equipment which was out on lease. Since IBM had begun marketing a newer and more powerful series which would make the 360 equipment less desirable, and since many of the leases could be canceled by the lessee on short notice, Arthar Andersen \& Co. proposed to qualify its opinion by stating that Boothe's financial statements were satisfactory "subject to the effect of the outcome . . . of future events with respect to rental revenues which the computer equipment will produce." Boothe promptly discharged Andersen and retained in its place Touche Ross \& Co., which gave a clean opinion. Now, When Auditors and Ciients Split Up After Feud, the Public Must Be Told Why, Wall St. J., Feb. 23, 1972, at 36, col. 1. Shortly thereafter another computer lessor, DCL, dismissed Price, Waterhouse \& Co., which had insisted on a qualification similar to that desired by Arthar Andersen, and retained Lybrand, Ross Bros. \& Montgomery, which did not. Diebold Parent Feels Cash Pinch, N.Y. Times, Sept. 26, 1972, at 63, col. 5.

For other recent cases of discharges based on disputes over accounting principles, see Hawes, Stockholder Appointment of Independent Auditors, 74 Colum. L. REv. 1, 3 n.11, 18 \& nn.98 \& 99 (1974) [hereinafter cited as Independent Auditors]; Hershman, Companies v. Auditors, 104 Dun's Rev., July 1974, at 33; Allegheny Beverage Fires Auditons Seeking to Force Lower Profit, Wall St. J., April 20, 1972, at 17, col. 2; ICN. Pharmaceuticals Fired 1ts Auditor Peat Marwick, in Dispute Over 1972 Net, Wall St. J., Sept. 6, 1974, at 9, col. 1; Investors Funding Fires Peat Marwick in Dispute Over Real-Estate Accounting, Wall St. J., Feb. 28, 1973, at 12, col. 2. See generally, Bedingfield \& Loeb, Auditor Changes-An Examination, J. Accountancy, March 1974, at 66.

181. Cf. Sterling, supra note 157, at 61-63. 
objective auditing of management's performance is and must be a central concern of the corporate system, and only through the accountant can such auditing be achieved. But the structure of the accountant's role is seriously - even fundamentally-flawed. It is impossible to expect objective reporting from an institutional structure which combines (1) power of selection of accounting principles by the very managers whose activities are being accounted for, (2) wide discretion in making that selection, and (3) auditing of that selection by persons hired and fired by the very managers who make the selection. ${ }^{182}$ As long as management rather than the accountant is empowered to make discretionary choices among competing accounting principles, such choices will often lack soundness and will invariably lack objectivity. As long as management hires and fires those who audit management, there can be no true auditing. To achieve an objective flow of informtaion on the results achieved by management, one of two conditions inust prevail. Either accounting principles must be made so narrow and mutually exclusive that selection among them becomes a mechamical rather than a discretionary act, or the power to select applicable accounting principles must be vested in accountants who are truly independent of management. ${ }^{183}$ Since the former condition is not practicably attainable, corporate law inust aim at establishing the latter.

\section{Responsibility for selecting accounting principles}

Although at first glance a shift of responsibility for selecting accounting principles from management to the accountants might appear so radical as to be unrealistic, in many respects it would simply carry to their logical conclusion a series of recent developments in the courts, the SEC, and the accounting profession itself. In the accounting profession, for example, in 1964 the AICPA Council issued a Special Bulletin recommending that financial statements disclose any departure from principles recognized by the APB, even where the principle

182. Cf. Foster, Securities, Balance Sheets and the Exchange, Com. \& Fin. Chron., Sept. 7, 1972, at 1, col. 1; Stering, supra note 157, at 61; Accounting Profession Assailed by SEC Aide For Lack of Skepticism, Wall St. J., Jan. 9, 1974, at 4, col. 3; Overhaul of Accounting Rule-Making System, Expected Today, Is Seen Reducing Conflicts, Wall St. J., May 2, 1972, at 42, col. 1; SEC Proposes Fuller Disclosure by Public Firms, Wall St. J., Dec. 19, 1972, at 2, col. 2.

183. See A. Briloff, The EFfectiveness of Accounting Communication 83-84, 136-37 (1967); Briloff, Corporate Financial Reporting Quagmire, Com. \& Fin. Chron., Jan. 13, 1972, at 1, col. 1; Kripke, supra note 166, at 1184-87; Miller, supra note 157, at 45-46; Sterling, supra note 157, at 66 Expanded Auditors Role Urged by SEC Official, N.Y. Times, Dec. 20, 1972, at 63, col. 6 .

Responsibility for the data underlying the financial statements would of course remain with management, while responsibility for auditing that data would renain with the accountants. See Kripke, supra note 166, at 1187. 
utilized in the statement has substantial authoritative support. ${ }^{184}$ In 1971 the APB issued Opinion No. 20, which stated a presumption that an accounting principle once adopted by a firm should not be changed in accounting for later events and transactions of a similar type-a presumption that can be overcome only by the justification that a new principle is preferable to the old one. ${ }^{185}$ In 1972 the AICPA replaced the part-time, practitioner-dominated APB with a Financial Accounting Standards Board (FASB), ${ }^{186}$ which is expected to narrow the choice of generally accepted accounting principles. ${ }^{187}$ In contrast to the APB, three of the FASB's seven members need not be CPA's, and all are to serve full-time five-year terms and must sever their former employment or partnership ties. ${ }^{188}$ Finally, in 1973 the AICPA adopted a new rule which makes it unethical for a member to "express an opinion that financial statements are presented in conformity with generally accepted accounting principles if such statements contain any departure from an accounting primciple promulgated by [the APB or FASB] which has a material effect on the statements taken as a whole,

184. Special Bull., supra note 165.

185. AicPA, Opinions of the Accounting Principles Bonkd No. 20, 390-91 (1971). See also SEC Reg. S-X, Rules 2.02(c)(2), 3.07(a), 17 C.F.R. $\$ \S 210.2-02$ (c) (2), 210.3-07(a) (1974). APB No. 20 distinguishes, however, between changes in "accounting principles" and "accounting estimates," and is much less rigorous as to changes in the latter category. (For a critique, see Frishkoff, supra note 155, at 64). Furthermore, many accountants have failed to follow the rules set out in APB No. 20. Sed Cushing, supra note 168.

186. AICPA Press Release, CPAs Adopt Wheat Report, May 3, 1972.

187. WhEAT REPORT, supra note 162, at 61-63, 70-75; Overhaul of Accounting Rule-Making System, Expected Today, Is Seen Reducing Conflicts, Wall St. J., May 2, 1972 , at 42 , col. 1 .

188. WHEAT REPORT, supra note 165 , at $37-43,54$. Members of the FASB are appointed by a newly created Financial Accounting Foundation, consisting of nine trustees: the president of the AICPA, ex officio, and eight trustees appointed by the AICPA's board for three-year terns, including four CPA's in public practice, two financial executives, a financial analyst, and an accounting educator. The latter four trustees are to be chosen from short lists submitted by certain named organizations. Id. at 69 .

A factor which may inhibit the FASB's ability to eliminate unsound accounting principles is that approval of an accounting standard requires the vote of five of its seven members, WHEAT REPORT, supra note 165 , at $73-74$, and any three members therefore have a veto. Professor Moonitz has predicted that the FASB will suffer the same fate as the APB:

The absence of an explicit framework, of a code of generally accepted accounting principles, will continue to frustrate the FASB just as it did the APB. Given such a code, the prognosis would be one of success for the FASB in its technical function of making policy decisions in the area of accounting standards. Without it, the FASB will repeat the experience of the APB. Some of its pronouncements will be inconsistent with other pronouncements. Individual pronouncements will be incomplete or vague, leaving the way open for new variations that will call for additional pronouncements. Partial solutions will parade as general standards and special imterest groups will have a field day as loopholes are discovered and exploited.

M. Moonitz, Obtaining Agreement on Standards in the Accounting Profession 83-84 (Am. Acct'g Ass'n Studies in Accounting Research No. 8, 1974). 
unless the member can demonstrate that due to unusual circumstances the fimancial statements would otherwise have been misleading."189

A second line of developments leading to increased responsibility for accountants is taking place in the courts and the SEC. To begin with, those accountants who do not meet even the minimuin standards of their own profession are being exposed to severe sanctions. Partners in Lybrand, Ross Bros. \& Montgomery ${ }^{190}$ and Peat, Marwick, Mitchell \& Co. ${ }^{101}$ have been found guilty of criminal violations. Arthur Andersen \& Co. has been censured by the SEC. ${ }^{192}$ Private actions against Haskins \& Sells, Arthur Andersen, Lybrand, Arthur Young, and Peat Marwick have been settled for amounts ranging from $\$ 300,000$ to just under $\$ 5$ million. ${ }^{193}$ As of 1973 , claims against accountants involving more than 500 compames were either in process or in litigation, ${ }^{104}$ and in 1974 Arthur Andersen alone had lawsuits pending against it involving 34 companies. ${ }^{195}$ The leavy pressure exerted by

189. See AICPA, Restatement of the Code of Professional Ethics Rule 203 (1972). Where a departure is justified under this test, the accountant's report "must describe the departure, the approximate effects thereof, if practicable, and the reasons why compliance with the [APB or FASB] principle would result in a misleading statement." Predecessor rules had merely required disclosure of a departure from generally accepted accounting principles, without giving any special weight to principles adopted by the APB. See AICPA, Code of Professional Ethics Rule 2.02(e) (1972 ed.).

The AICPA's trial board is empowered to admonish or expel a member for violations of professional ethics, but has no power to impose fines or to bar a person from the practice of accounting. It has been charged that the AICPA's enforcement of its ethics code has been less than rigorous. Accounting Institute Votes Code Requiring Auditors to Follow Principles Board Rules, Wall St. J., Jan. 22, 1973, at 4, col. 2.

Although rule 203 does not explicitly require disregard of authoritative principles whose application would result in unfair presentation, an interpretation issued by the AICPA's Division of Professional Ethics states that "upon occasion there may be unusual circumstances where the literal application of pronouncements on accounting principles would have the effect of rendering financial statements misleading. In such cases, the proper accounting treatment is that which will render the financial statements not misleading." AICPA, Restatement of the CODE of Professional Ethics 35 (1972).

190. U.S. v. Simon, 425 F.2d 796 (2d Cir. 1969), cert. denied, 397 U.S. 1006 (1970).

191. Two Auditors Are Convicted of Stock Fraud, Wall St. J., Nov. 15, 1974, at 8 , col. 2.

192. Arthur Andersen Censured by SEC over Whittaker, Wall St. J., July 9, 1974, at 4 , col. 1 .

193. See L. \& J, GILbert, THirty-SeCOND ANnUAL Report 248 (1971); Arthur Young Agrees to Settle Suit for $\$ 950,000$, Wall St. J., Sept. 4, 1973, at 22, col. 1; Louisiana \& Southern, Auditor to Settle Suit with Payout of Stock, Wall St. J., Oct. 6, 1972, at 4, col. 3; Peat Marwick, Allen \& Co., Inc., Others, Quietly Settle Fraud Suit for $\$ 2.9$ Million, Wall St. J., Dec. 9, 1974, at 12, col. 2.

194. ARThUR ANDERSEN \& Co., 1973 Annual Report 4. See also Louis, supra note 166 , at 177 .

195. Arthur Andersen's 1974 Report Indicates it Will Keep Growing, Fight Litigation, Wall St. J., June 24, 1974, at 10, col. 2. 
this criminal and civil litigation is causing accountants to be both more careful and more scrupulous in observing their own mininal standards. ${ }^{196}$

Of perhaps greater import, the courts are beginning to upgrade the standards of the profession in the first instance. ${ }^{107}$ This upgrading is most dramatically exemplified by Escott v. BarChris Construction Corp. ${ }^{198}$ and United States v. Simon. ${ }^{109}$ The BarChris case, discussed earlier, focused on liability for certifying a principle that does not fairly account for the transaction being described; Simon focused on liability for certifying a financial statement that is unfair taken as a whole.

The problein in Simon grew out of the use by Harold Roth of two corporations under his control, Continental and Valley, to finance personal stock-market transactions, by causing Continental to loan money to Valley, which in turn lent the money to him. The purpose of making the loans through Valley, rather than directly from Continental to Roth, was to dress up Continental's balance sheet: the loans were shown on Continental's books as an account receivable from Valley rather than froin Roth. At the end of fiscal 1962, Continental's account receivable froin Valley arising out of loans destined for Roth exceeded \$3.5 inillion. Before Continental's fimancial statements for that year were certified, its accountants learned that the Valley receivable was uncollectible (and therefore could not be shown on Continental's books as an asset) because Roth was unable to repay Valley the amount it had lent him, an amount far exceeding Valley's net worth. To remedy this, Roth collateralized the Valley receivable, but the collateral consisted principally of stock and convertible debentures in Continental itself. The accountants, aware of all the relevant facts, nevertheless certified the $\$ 3.5$ million Valley receivable with only the following qualification, which appeared in a footnote:

The amount receivable from Valley Commercial Corp. (an affiliated company of which Mr. Harold Roth is an officer, director and stockholder) bears interest at $12 \%$ a year. Such amount, less the balance of the notes payable to that company, is secured by the assignment to the Company of Valley's equity in certain marketable securities. As of February 15, 1963, the amount of such equity at current market quotations exceeded the net amount receivable. ${ }^{200}$

196. See Hershman, supra note 180 , at 33, 35; Now, When Auditors and Cllents Split Up After Feud, Public Must be Told Why, Wall St. J., Feb. 23, 1972, at 36, col. 1; SEC Jolting Auditors Into a Broader Role in Fraud Detection, Wall St. J., July 6, 1974, at 25, col. 2.

197. Cf. Sommer, Survey of Accounting Developments in the 60's; What's Ahead in the 70's, 26 Bus. LAw. 207 (1970).

198. 283 F. Supp. 643 (S.D.N.Y. 1968), discussed at text accompanying notes 169 70 supra.

199. 425 F.2d 796 (2d Cir. 1969), cert. denied, 397 U.S. 1006 (1970).

200. Id. at 800 (emphasis added). 
Subsequently the accountants were indicted under the Securities Exchange Act for certifying a false or misleading financial stateinent. ${ }^{201}$ At the trial they called as witnesses eight expert accountants, constituting, in the words of the Second Circuit, "an impressive array of leaders of the profession," who testified that the failure to disclose in the footnote the purpose of the loans to Valley and the nature of the collateral was in no way inconsistent with generally acceptable accounting principles. ${ }^{202}$ The defendants asked for instructions which, in substance, would have told the jury that "a defendant could be found guilty only if, according to generally accepted accounting principles, the financial statements as a whole did not fairly present the financial condition of Continental at September 30,1962, and then only if his departure from accepted standards was due to willful disregard of those standards with knowledge of the falsity of the statements and an intent to deceive."203 The trial court declined to give this instruction-which would have given the defendants a complete defense in light of the expert testimony-but instead instructed that the critical issue was whether the financial statements as a whole fairly presented Continental's financial position and accurately reported its operations. If they did not, the basic issue was whether defendants had acted in good faith. Proof of compliance with generally accepted accounting principles would be "evidence which may be very persuasive but not necessarily conclusive" on that issue. 204

A jury verdict against the accountants was sustained by the Second Circuit in an opinion by Judge Friendly. Thereafter, in a speech to the AICPA, the Chairman of the SEC described the result of the case as follows:

[T] he court established that it is not enough to merely adhere to rules, even if they are generally accepted principles or standards. Rather a critical test is whether the financial statement, as a whole, fairly presents the position of the company and accurately reports its operation for the period it purports to cover. To meet this test and establish good faith, an accounting report has to reflect pertinent infornation which those who prepare it have, or in due diligence,

201. The indictment was based on (1) the failure of the note to disclose the purpose of the loans to Valley and the nature of the collateral, and (2) the fact that in determining the value of the collateral and the extent to which the Valley receivable was collateralized, the accountants improperly netted Continental's account payable to Valley against its Valley receivable, failed to discover that there was a lien of $\$ 1$ million against the pledged securities, and failed to disclose that the amount of the receivable had risen by $\$ 400,000$ between the end of the fiscal year and the date of certification, while the value of the collateral had declined by more than $\$ 270,000$ between the date of certification and the date the financial statements were mailed. Id. at 801,805 08.

202. Id. at 805 (except for the erroneous netting).

203. Id. (emphasis added).

204. Id. 
should obtain, whether or not the disclosure of that information is required by specific generally accepted principles or standards. ${ }^{205}$

To put the matter differently, just as BarChris held, in effect, that an accountant cannot rely on general acceptance to support his certification of a principle that does not fairly account for the transaction being described, Simon held that an accountant cannot rely on the general acceptance of each principle employed in the preparation of a financial statement to support his certification of a statement that is not fair as a whole. To comply with these decisions the accountants will need to increase significantly their control over the financial statements they certify. Taken together with the cases holding accountants to their own existing standards, as well as the trends within the accounting profession itself, BarChris and Simon mdicate that a shift of power over the selection of accounting principles utilized in the preparation of financial statements from the managers to the accountants is not only appropriate on policy grounds, but also carries forward an institutional momentum that seems to be building to just such a climax.

\section{Selection and Dismissal}

Vesting in the accountants responsibility for the selection of accounting principles is a necessary condition to ensure the integrity of financial statements, but not a sufficient one. As long as selection among competing accounting principles is discretionary, the purpose of such a shift could be subverted too easily if management itself retained the power to select and dismiss the accountants. As a second structural reforn, it is therefore necessary to shift that power too out of management's hands. ${ }^{208}$ One proposal to accomplish this objective is embodied in the thorough and persuasive argument of Douglas Hawes that the power to appoint and dismiss a corporation's accountant should reside in the body of shareholders rather than the board. ${ }^{207}$ Left to itself, lowever, that body would undoubtedly look to the board for guidance on selection and dismissal, could neither determine the scope of the audit nor the compensation of the accountant, and could not give the accountant periodic direction and support. A complementary step is therefore necessary: Every publicly held corporation should be required to have an audit committee, comprised entirely of independent directors, which would have the exclusive power (1) to nominate and recommend dismissal of the corporation's accountant on behalf of

205. The Partnership Between the Accounting Profession and the SEC, Address by William Casey, chairman of the SEC, before the AICPA, Oct. 2, 1972.

206. Cf. Hoenmeyer, supra note 163, at 33; Sterling, supra note 157, at 66 . at 33; Sterling, supra note 157, at 66.

207. Independent Auditors, supra note 180. 
the board, and (2) to direct the accountant's activities and set the terms of his engagement. ${ }^{208}$

As in the case of responsibility for financial statements, the shift of power here proposed, while new in form, would simply carry to its conclusion a practice that has been gaining momentum as a voluntary institution. Professor Hawes reports that 57 of the 100 largest industrials, and 3121 of the 7000 corporations filing proxy statements with the SEC, already submit the choice of accountant to the shareholders in some fashion. ${ }^{200}$ The percentage of publicly-held corporations with audit committees composed of outside directors is probably comparable.

Such committees were authoritatively proposed in this country as early as 1940 by the SEC. ${ }^{210}$ The AICPA announced in favor of such committees in $1967,{ }^{211}$ and a number of individual accounting firms have since climbed on board. ${ }^{212}$ In 1972 the SEC issued a second release on the subject, which concluded with the statement that "the Commission . . . endorses the estabhisliment by all publicly-held companies of audit committees composed of outside directors," and urged the business and financial communities and shareholders to lend full

208. Audit committees also carry certain collateral advantages. An accountant will frequently have reservations, questions, or information which is not important enough or otherwise appropriate for inclusion in his formal opinion, but which should be brought to the board's attention. Cf. R. Mautz \& F. Neumann, Corporate Audit CommitTeEs 85 (1970) [hereinafter cited as MaUtz \& NeUMANn]; Touche Ross \& Co., CoRPorate AUdiT COMMrTteEs 9 (1970). The whole board, however, is typically too large to hold im-depth discussion with the accountant and too busy to meet with him frequently. See MAUTZ \& NEUMANN, supra, at 7, 52. The existence of an audit committee obviates these problems.

Hawes also proposes that an audit committee be required in publicly held corporations. His proposal would not, however, require the committee to consist of independent direetors, although this was largely because he felt that "the idea of [requiring independent] directors on the boards of all public companies .... is not central to the proposal [that auditors be elected by the shareholders], and would unnecessarily burden the debate thereon." Independent Auditors, supra note 180, at 37.

209. Independent Auditors, supra note 180, at 12.

210. SEC, Accounting Series Release No. 19 (Dec. 5, 1940). This report, which was a response to McKesson \& Robbins debacle, recommended that a committee of outside directors be established "to make all company or management nominations of auditors and ... [ [to arrange] the details of the engagement." The report also called for shareholder election of auditors.

211. AICPA Executive Committee Statement on Audit Committees of Boards of Directors, J. AccountancY, Sept. 1967, at 10.

212. For example, Touche Ross \& Co. issued a brochure and a 27-mmute color film on audit committees, and the Touche Ross foundation sponsored a major study of such committees by Mautz \& Neumann. See ToucHE Ross \& Co., supra note 208; $A u$ ditors, Outside Directors Set Up Panels To Find Firms' Woes Before Crises Occur, Wall St. J., May 31, 1972, at 32, col. 1. See also, e.g., ARTHur ANDERsen \& Co., The Audit COMMITTEe OF THE BOARD OF DIRECtORs (1972); ARTHUR ANDERSEN \& CO., 1974 ANNUAL REPORT 4. 
support to implementation of that endorsement. ${ }^{213}$ Finally, in a 1973 White Paper the New York Stock Exchange strongly recommended that every listed company form an audit committee consisting of three to five outside directors, and in 1974 the SEC issued still a third release, requiring registered corporations to disclose in their proxy materials either the composition or nonexistence of an audit committee. ${ }^{214}$

The results of this developing momentum are reflected in the data. A report by the Conference Board in 1967 found that only 19 percent of the surveyed manufacturimg and 21 percent of the nonmanufacturing corporations had audit committees. In a comparable survey in 1973, the figures had jumped to 45 percent and 46 percent respectively. ${ }^{215}$ Of these, 97 percent had at least a majority of outside directors, and over 83 percent consisted entirely of outside directors. ${ }^{210}$ As of 1972, 35 of the country's 50 largest corporations had audit committees, nime having adopted such a committee between 1967 and 1972. ${ }^{217}$

213. SEC, Accounting Series Release No. 123 (March 23, 1972).

214. New York Stock Exchange, Recommendations and Comments on Financial Reporting to Shareholders ANd Related Matrers 6 (1973); SEC Securities Act of 1933 Release No. 5550 (Dec. 20, 1974).

215. 1973 CONFERENCE BOARD SURVEY, supra note 14, at 50-51. In other samples during this period, 32 percent of 385 corporate respondents in a survey by Mautz and Neumann reported they had auditing committees, MAUTZ \& NeUMaNn, supra note 208, at 14 Table 2, as did 30 percent of 797 respondents in a survey by the Financial Executives Institute, Hobgood \& Sciarrino, Management Looks at Audit Services, Financial EXECUTTVE, April 1972, at 29-30, and 42 percent of 750 respondents in the Heidrick \& Struggles survey, HeIDRICK \& STRUGGLES, supra note 12, at 6.

216. 1973 CONFERENCE BoARd SURVEY, supra note 14, at 64 (Table 21).

217. Vanderwicken, supra note 52, at 159. See also Auditors, Outside Directors Set Up Panels To Find Firms' Woes Before Crises Occur, Wall St. J., May 31, 1972, at 32, col. 1. Similarly, 40 percent of the 121 committees reported in response to the Mautz \& Neumann survey were formed during the period 1965-1970. MAUTz \& NeUMANN, supra note 208, at 9.

The Mattel consent decree, see note 128 supra, requires Mattel to establish a Financial Controls and Audit Committee consisting of four directors, at least three of whom are to be imdependent directors appointed pursuant to the decree's provisions. In case of disagreement or controversy between the accountants and management, "[t]he Committee shall determine the position of Mattel in such disagreement or controversy and Mattel shall abide by and act in accordance with any such determination by the Committee." The Committee also has the duty of approving or disapproving any change of accountants. SEC v. Mattel, Inc., CCH SEC. REG. REP. I 94,807 (D.D.C. 1974).

Similarly, under the Northrop settlement, see note 128 supra, Northrop's Audit Committee is required to consist entirely of independent directors. The Committee:

1. ... [S]hall nominate to the shareholders on behalf of the Board, the Corporation's auditors and shall have power, on behalf of the Board, to propose to the shareholders the removal of the auditors at the annual shareholders' meeting or at a special shareholders' meeting called for that purpose.

2. In case of a vacancy in the position of auditor occurring otherwise than through removal ... . shall appoint an auditor to fill the vacancy until the next annual shareholders' meeting.

3. ... [S]hall arrange the details of the auditors' engagement, including fixing the auditors' remuneration. Springer v. Jones, Civ. No. 74-1455-F (C.D. Cal. Nov. 23, 1974). 
In a recent survey of the 1563 companies listed on the New York Stock Exchange, 80 percent of 1083 respondents reported they had an audit committee, and another 13 percent had plans to establish such a committee. Of the existing committees, 84 percent consisted exclusively of outside directors, and 95 percent had a majority of such directors. ${ }^{218}$

There are also impressive legislative precedents for shifting the selection and dismissal of accountants from management's hands to the board's. The Investment Company Act requires that a registered investment company's accountant be selected by a majority of the board's dismterested directors and approved by the shareholders. ${ }^{219}$ Enghish statutory law has for many years required that auditors be elected and dismissed by the shareholders; ${ }^{220}$ comparable procedures are provided by the Canada Corporations Act ${ }^{221}$ and the statutes of most of the Canadian provinces, ${ }^{222}$ most notably the Ontario Business Corporation Act. ${ }^{223}$ Experience under the English statute suggests that this difference in structure is likely to have substantive consequences as to the auditor's independence. In several widely publicized in-

218. WHTTE PAPER RESPONSE, supra note 124, at 3.

219. 15 U.S.C. \& 80a-31(a) (1970).

220. The Companies Act of $1948,11 \& 12$ Geo. 6, c, 38, $\S 159(1)$ [hereinafter cited as Companies Act of 1948]; Independent Auditors, supra note 180, at 5 n.20. The board may appoint an auditor before the first general shareholders' meeting, and may fill vacancies caused by the auditor's death, disqualification, or legal incapacity. Companies Act of $1948, \S 159(5)(\mathrm{b})$, (6). Where disinissal is proposed, the auditor must be given notice of the proposal and is entitled to require the corporation to circulate his written statement to the shareholders, Companies Act of $1948, \$ 160(1)-(3)$, and then to present his case orally at the shareholders' meeting. The Companies Act 1967, $\mathrm{c}$. 81, \$ 14(7). For a detailed description of the English law, see Independent Auditors, supra note 180, at 4-9. The English statute further strengthens the auditor by giving him a right of access at all tines "to the books and records and accounts of the company," a right "to require from the officers ... such information and explanation as he thinks necessary" for the performance of his duties, and a right to attend all shareholders meetings, receive all notices and other communications that a shareholder is entitled to receive, and be heard at any such meetings on any matter which concerns him as auditor. The Coinpanies Act of 1967 , c. 81 , $\S 14(5)$, (7). Gower states that "These legal provisions are supplemented by a strictly observed rule of etiquette of the accountancy profession whereby an auditorship is not undertaken without prior consultation with the feriner auditor to ensure that there is no reason why the post should not be accepted." L. GowER, supra note 147, at 469 n.78.

221. Canada Corporations Act, CAN. Rev. Stat. c. C-32, §§ 130-32 (1970).

222. See Independent Auditors, supra note 180, at 11 n.56.

223. Ontario Business Corporations Act, ch. 53, §§ 167-71, [1970] Ont. Rev. Stat. 445-50. The Ontario statute requires publicly held corporations to have audit committees consisting of at least three directors, a majority of whom are outsiders, but does not require the committee to play a formal role in the appointment, tenure, and removal of the corporation's accountant. Id. $\$ 182$. Indeed, the precise role of the committee generally is unclear, although the legislative intent apparently was to insulate the auditor from management pressures. See Iacobucci, The Business Corporations Act, 1970: Management and Control of a Corporation, 21 U. TORONTO L.J. 543, 546 (1971). The proposed new Canada Business Corporations Act contains provisions similar to those in Ontario. Bill C-29, §§ 159-65, House of Commons, 30th Parl., 1st Sess. (Can. 1974). 
stances accountants in England have successfully resisted management's efforts to discharge them. ${ }^{24}$ Comparable results can be expected in this country, because of the increasing pressures toward independence and because resistance to management attempts at discharge would be in the accountants' own financial self-interest. ${ }^{225}$

\section{An Auditing Capability for the Restructured Board}

Although the primary role of the accountant is to audit management's financial results, once the accountants have been made independent they will provide a capability enabling directors to audit management's performance in other areas as well. Through this capability, for example, the board can acquire objective and reliable data not only on net profits, but on such nonfinancial indicators as market penetration and comparative costs. ${ }^{226}$ Going one step further, through this

224. Douglas Hawes describes one such case: the 1963 effort by the management of The City of London Real Property Co., Ltd. to replace its auditors. Management settled a dispute over accounting treatment by yielding to the accountants but at the next annual meeting proposed that new auditors be appointed on the ground that mutual confidence no longer existed between the board and the auditors. The English professional accountants' association took sharp exception:

The existence of such a possibility [of a difference of opinion between the directors and the auditors] is among the reasons why auditors are appointed. The work of the auditors and their freedom to perform it with a sense of complete independence can only continue as long as it is generally accepted that the issue by auditors of a report expressing disagreement with the directors of a company of which they are auditors does not of itself provide a reason for the removal of the auditors from office. The purpose implicit in the appointment of auditors under the Companies Act would be defeated if there were to grow up a practice of displacing auditors whenever a disagreement between them and the directors of a company occurs on a matter of accounting principle.

The Association of Investment Trusts took the accountants' side by recommending that those of its members whose trusts owned stock in the company vote against the proposal. As a result of this stand and shareholder opposition, management withdrew its recommendation. Independent Auditors, supra note 180, at 7-8.

225. From the perspective of investors, freeing the accountant from management's control is a necessary condition to ensuring the integrity of financial statements, but not necessarily a sufficient one, because even independent directors may pressure the accountant to paint an unduly favorable picture for the public eye. This danger should not be exaggerated, however, since independent directors would generally have little reason for exerting such pressure-on the contrary, they would risk exposure to a liability out of all proportion to their directors' fees and perquisites. Nevertheless, the danger, however minimal, still exists, and a restructured role for the accountant should not in itself relieve the FASB and the SEC from the responsibility to narrow the choice of accounting principles.

226. Two examples of the potential value of a capability for acquiring reliable information on such indicators follow:

Standard Oil of New Jersey received . . . a shock not long ago. Says . . . one of its executives... . : "You can't begin to tell how good or bad you are until you have figures. A few years ago [Standard Oil] was hard hit by the competition of small local refineries. People started saying that these companies were more efficient than we were, but we wouldn't believe this because it was inconsistent with our self-image. When we got comparative data, man- 
capability the board can audit the soundness of the corporation's underlying control systems, such as its capital- and operating-budget processes, cash- and sales-forecasting techniques, and conflict-of-interest procedures. ${ }^{227}$ Finally, the capability brought to the board by truly independent accountants would enable it to audit management's results in meeting relevant nonfinancial objectives, such as comphance with law, ${ }^{228}$ due respect for the environment, provision of safe working conditions, nondiscrimination, and fair treatment of the consumer. ${ }^{228}$

These functions would not be completely new to accountants. Comparable audits have long been performed on behalf of government, ${ }^{230}$ and the profession has recently begun performing "manage-

agement was first incredulous, then astounded. Finally it started doing something about the problem.

Rose, The News About Productivity Is Better Than You Think, ForTUne, Feb. 1972, at $98,188$.

By last fall, dissatisfaction [with Najeeb Halaby, Pan Am's president] had reached its highest point. A veteran director told Halaby that he was receiving direct reports of problems from several upper-level executives. At about the same time, statistics prepared by Pan Am for the T.W.A. merger negotiations jolted a number of directors into recognizing just how serious the situation had become.

T.W.A. and Pan Am are by no means perfectly comparable, because T.W.A. has a big domestic network. . . B But over the North Atlantic, where their operations are comparable, T.W.A.'s costs per available ton-mile (i.e., the total capacity of all planes multiplied by the number of miles flown) are substantially better. Through nine months of last year, T.W.A.'s costs amounted to 15.74 cents, against Pan Am's 19.01 cents. Had Pan Am's cost ratio been as good as T.W.A.'s it could have converted its operating loss of almost $\$ 7 \mathrm{mil}-$ lion into a substantial profit.

Cordtz, Pan Am's Route Across The Sea of Red Ink, ForTune, Jan. 1972, at 78, 146.

227. See Burton, Management Auditing, J. AccounTancy, May 1968, at 41; Campfield, Trends in Auditing Management Plans and Operations, J. AccounTancy, July 1967, at 41; Dodwell, Operational Auditing: A Part of the Basic Audit, J. AccounTANCX, June 1966, at 31; Witte, Management Auditing: The Present State of The Art, J. AccountancY, Aug. 1967, at 54; cf. Auditors, Outside Directors Set Up Panels To Find Firms Woes Before Crises Occur, Wall St. J., May 31, 1972, at 36, col. 1. But cf. Norgaard, The Professional Accountant's View of Operational Auditing, J. AcCOUNTANCX, Dec. 1969 , at $45,47-48$.

228. Cf. Melamed \& Baker, Outside Directors, 6 Rev. Sec. REg. 915, 921-22 (1973).

229. Under the Northrop settlement, see note 128 supra, Northrop's audit committee, which must consist entirely of independent directors, is given the power "to direct the outside independent auditors and the Corporation's internal audit staff to inquire into and report to it on any corporate contract, transaction, or proeedure, the conduct of any corporate office, division, profit center, subsidiary, or other unit, or any other matter having to do with the Corporation's business and affairs." Springer v. Jones, Civ. No. 74-1455-F (C.D. Cal. Nov. 23, 1974).

230. See Morse, Performance and Operational Auditing, J. Accountancy, June 1971, at 46; Inquiry into Democratic Break-In Strips General Accounting Office of Some of Its Anonymity, N.Y. Times, Sept. 3, 1972, at 38, col. 2. For examples, see 1974 Comptroller Gen. U.S. ANnual Report passim; Lockheed Unit Faces Major Problems on Trident Sub Missile, GAO Study Says, N.Y. Times, April 7, 1975, at 2, col. 3. 
ment" or "operational" audits on behalf of business corporations. 201 Until now, however, such audits have usually been performed as a service to management rather than a check upon it.

\section{CONCLUSION}

Although it is widely held that the board should be actively involved in making business policy, the performance of such a role by the board is normally neither critical to the corporation nor achievable in practice. A corporate organ cannot be meaningfully involved in making business policy unless its members are highly active. It is not realistic, however, to expect a high degree of activity from the board. Directors may be highly active because they are executives; but in that case their activity does not derive from their directorial capacities, and the board cannot meaningfully be considered as a separate corporate organ. Directors may be highly active because they work at their directorships full-time, although they are not involved in operations; but this type of board is unsuitable for many or most corporations. Directors may be highly active because they are professional directors who make a career out of a dozen or so directorships, and are therefore able to devote significant time to each one; but there is no suitable population from whom the necessary number of professional directors can be drawn, and even if there were the logistics would inevitably involve either very heavy use of aged directors or massive board interlocks.

The major effect of according the policymaking function central importance, therefore, has been to divert legal and corporate institutions from implementing a function that is both critical and achievable: monitoring. Unlike policymaking, monitoring does not require a high level of board activity. It does require that the board has an adequate flow of objective information and that the directors, or at least a clear majority of them, be independent of the chief executive. These two conditions, however, can be implemented to a significant degree by formal rules governing organizational structure; specifically, the structure of the board, the responsibility of the accountant, and the relation between the accountant and the board.

In dealing with questions of organizational structure, it is always necessary to keep in mind the limits on the subject's importance. Writ-

231. See articles cited in note 227 supra. Questions have been raised as to whether performance of such services may impinge on an auditor's independence. See Burton, supra note 227, at 45; Hylton, Are Consulting and Auditing Compatible?-A Contrary View, 39 Accounting Rev. 667 (1964); Schulte, Compatability of Management Consulting and Auditing, 40 Accountivo REv. 587 (1965); cf. SEC, Accounting Series Release No. 126 (July 5, 1972). However, these questions should be largely obviated if the services were performed for an independent board. Cf. Carmichael, Some Hard Questions on Management Auditing, J. AccounTaNCY, Feb. 1970, at 72. 
ing in 1904, the corporate scholar Franz Klein referred to a concept he called "the truth of the form," meaning that certain forces are active in any given corporation, and that corporate organizational structure will in the end conform to those prevailing forces. ${ }^{282}$ There is much bite to this concept, and it would be self-deception to believe that great changes in organizational structure will necessarily produce great changes in the way a given organization actually functions, let alone great changes in the general economic structure of society. There is an iron paradox which governs corporate affairs, and no amount of restructuring can entirely avoid its force: Only those who are involved in an enterprise full-time liave sufficient knowledge to direct an enterprise, while only those who are not involved full-time can be trusted to inonitor those who direct. But having recognized these truths, it must also be recognized that even sinall institutional gains may be im. portant in the case of institutions which dominate our economic life; 283 that law reform should not confine its attention only to those clianges which will assuredly produce great effects; that corporate law is already concerned largely with questions of form and structure, often in intimate detail; and, finally, that admitting the importance of personal forces in any organization, it is nevertheless vital to structure organization so as to cliannel as far as possible the operation of those forces towards socially desirable objectives.

232. F. KIEIN, DIE NEUREN ENTWICKIUNGEN IN VeRFASSUNG UND RECHT DER AztIENGesellschaft 55 (1904); cf. The CoMpany 158-61 (C. de Hoghton ed. 1969); Buxbaum, Antitrust Policy in Modern Society: Dilemmas and Needs, in DAS UNTERNEHMEN IN DER RechtsordNUNG: Festgabe Für HeINRICH KRONSTEIn 1345, 1355-56 (K. Biedenkopf, H. Coing, E. Mestmäcker eds. 1967).

233. For example, the Handlins have convincingly argued that in its original form the corporation presented few advantages over other competing forms of business organization. Handlin \& Handlin, Origins of the American Business Corporation, $5 \mathrm{~J}$. EcoN. Hist. 1 (1945). Yet those slight advantages were nevertheless sufficient to cause the corporation to become the overwhelmingly dominant form of business organization over the course of time. 